\title{
La alta nobleza en la Cancilleria real castellana del siglo XV
}

\author{
Rosa M. ${ }^{a}$ Montero Tejada \\ M. ${ }^{a}$ José Garcia Vera
}

\section{INTRODUCCIONN}

A pesar de que a lo largo de los últimos veinte años se han multiplicado los estudios, tanto en torno al estamento nobiliario - por parte de diversos autores entre los que cabe destacar a M. A. Ladero, E. Mitre. M. C. Gerbet y M. C. Quintanilla-como en torno al funcionamiento de los principales órganos de la Administración central castellana - a través de las publicaciones de autores tales como S. de Dios, D. Torres Sanz y M. de la S. Martín Postigo entre otros-, en el ámbito de la historiografia medieval española - a diferencia de las trayectorias seguidas en otros países como Francia o Portugal- no contamos hasta el momento con estudios monográficos que se ocupen del ejercicio del poder politico de la alta nobleza castellana a través del desempeño de cargos y oficios en los órganos de gobierno y Administración central. En este sentido, hay que mencionar, sin embargo, los trabajos de M. C. Quintanilla Raso, que en los últimos años ha llamado la atención sobre la necesidad de elaborar una historia social del estado, de los órganos e instituciones, con una perspectiva distinta a la que han empleado los especialistas en historia de las instituciones políticas, poniendo en práctica una metodología ya ensayada en otros ámbitos, y que no es otra que la realización de una "oligarcología" o descripción y valoración de la clase en el poder, estableciendo nóminas de los distintos oficios '.

Véase Quintanilla Raso, M. C., "La nobleza en la historia politica castellana en la segunda mitad del siglo xV. Bases de poder y pautas de comportamiento". Actas del Congresso Internacional Bartolomeu Dias e sua Epoca, I. Oporto 1989, págs. 181-200 y "Historiografia de una élite de poder: la nobleza castellana bajomedieval". Hispania, n." 175 (1990). págs. $719-736$. 
Es por eso que siguiendo la línea de investigación iniciada hace ya algunos años en la historiografia portuguesa por autores como A. L. de Carvalho Homem, H. Baquero Moreno o L. Adao de Fonseca y en la francesa, por P. Contamine, P. R. Gaussin o M. Harsgor. en muchos casos para otros paises y épocas, pretendemos, sobre la base de la utilización del método prosopográfico, realizar una valoración de lo que supuso para la alta nobleza el desempeño de cargos públicos en el contexto histórico social de fines de la Edad Media.

Para ello hemos elegido la Cancilleria real castellana del siglo xv, por considerar no sólo que en este organismo la presencia del estamento nobiliario fue muy elevada, sino también porque a lo largo de esta centuria conviven en ella otros grupos de extracción social inferior - fundamentalmente letrados- ante la necesidad de incorporar a individuos más capacitados profesionalmente para hacer frente a la complejidad burocrática cada vez mayor que se observa durante todo el periodo bajomedieval. Esta convivencia de distintas fuerzas sociales en el seno de la Cancillería nos plantea una serie de hipótesis de trabajo de gran interés. En primer lugar seria necesario conocer con mayor exactitud cuál fue el grado de desempeño efectivo de los oficios por parte de la alta nobleza, en la que en muchos casos tan solo recayó la titularidad de los mismos. En segundo lugar, conviene adentrarse en las motivaciones que impulsaron a la nobleza a permanecer en los cargos, pues aunque esta cuestión podria resolverse en muchos casos atendiendo a factores tales como el prestigio social, la proximidad al monarca o la posibilidad de intervenir en el gobierno, en otros, es necesario recurrir a otro tipo de motivaciones o a la conjugación de varios de los factores señalados. Sabemos, por ejemplo, que era frecuente que los segundones de algunos de los principales linajes castellanos recurrieran al desempeño de cargos públicos como una de sus principales fuentes de ingresos. En tercer lugar, hay que investigar a fondo las relaciones entre las distintas fuerzas sociales que intervinieron en el funcionamiento de la Cancilleria. $Y$, por último, conviene valorar cuál fue la intervención regia en todo ello, teniendo siempre presente la dificil situación por la que atravesó la institución monárquica como consecuencia del enfrentamiento entre nobleza y monarquia a lo largo del siglo XV.

De este modo, el proyecto de elaborar un estudio de los personajes de la alta nobleza que tuvieron presencia en los distintos oficios de la Cancilleria real castellana, puede proporcionarnos noticias muy interesantes sobre la dimensión social de los mismos y sobre la intervención de la nobleza en las tareas administrativas y gubernativas, intervención que entendemos como una de las amplias bases del poder nobiliario en la Castilla del siglo $\times V$. 
Para la realización de este trabajo ha sido necesaria la consulta de datos documentales inéditos y dispersos que, aglutinados con coherencia, nos han permitido ofrecer un panorama general sobre los principales personajes que ejercieron cargos en la Cancilleria real castellana del siglo $X V$, con el que no contábamos hasta el momento, a pesar de que el interés que el estudio de la Cancillería real castellana ha despertado en los últimos treinta años ha sido constante, reflejándose en la gran cantidad de estudios publicados desde la aparición de los trabajos ya clásicos de E.S. Procter $^{2}$, L. Sánchez Belda ${ }^{3}$, M. de la S. Martín Postigo ${ }^{4}$ y F. Arribas Arranz ${ }^{5}$.

Sin embargo, para el periodo bajomedieval no encontramos gran número de publicaciones hasta mediados de la década de los setenta, en que comienzan a aparecer trabajos que se ccupan de las cancillerias reales castellanas con caracter monográfico ${ }^{6}$. En este sentido, los estudios de L. Pascual Martinez', centrados en su mayor parte en el siglo xıv, vinieron a paliar un poco esta escasez de trabajos.

Procter. E. S., The Castilian Chancery during the Reign of Alfonso X. Oxford 1934.

Sanchez Belda. L., "La Cancilleria castellana durante el reinado de Sancho IV (12841295)", Anuario de Historia del Derecho Español, XXI-XXII (1951-1952). págs, 171-223.

Martin Postigo, M. de la S., La Cancilleria castellana de los Reyes Católicos. Valladolid 1959: "La Cancilleria castellana en la primera mitad del siglo xvi». Hispania. t. XXIV. págs. 348-367 y 509-551; “La Cancilleria real castellana en la segunda mitad del siglo XVi", Hispania, t. XXVIl, págs. 381-404; "Registrador Mayor y Chanciller del Sello Mayor en la segunda mitad del siglo xvi", Homenaje al prof. Alarcos Garcia. t. II (1965-1967). pags. 721-731: "Los lugartenientes en la Cancilleria real castellana (1516-1568). Actuación de don Fernando Valdés", Simposio Valdés Salas. Universidad de Oviedo, 8-11 de diciembre de 1968; "El Chanciller Mayor del Sello Mayor en la Cancilleria Real castellana (siglos xvII-xix)m, Miscelánea Marin Ocete, 11, 615-636. Granada 1974: "Notaria Mayor de la Privilegios y Escribania Mayor de los Privilegios y Confirmaciones en la Cancilleria Real castellana". Actas de las Primeras Jornadas de Metodología Aplicada a las Ciencias Históricas V. Paleografia y Archivística. Santiago de Compostela 1975; Historia del Archivo de la Real Chancillería de Valladolid. Valladolid 1959; "Las Cancillerías reales castellanas. Estado actual de los estudios", Separata del Boletín de la Sociedad Castellonense de Cultura, t. LVIII, Cuaderno III. 1982, págs. 513-547.

Arribas Arranz, F., Sellos de placa de las cancillerias regias castellanas. Valladolid 1941; "Los registros de Cancilleria de Castila". Boletin de la Real Academia de la Historia, CLXIII (1968), cuaderno 1, págs. 143-162 y cuaderno 2, págs 171-200: "Un formulario documental del siglo xv en la Cancilleria castellana". Cuadernos de la Catedra de Paleografía y Diplomática, IV Valladolid. 1964; Estudios sobre Diplomática castellana de los siglos xv y xvi. Valladolid 1959; "La carta y la provisión real». Cuadernos de la Cátedra de Paleogratia y Diplomática, II. Valladolid 1959.

- Véase sobre el particular: CANellas. A., "La investigación diplomática sobre cancillerias y oficinas diplomáticas: estado actual". Actas de las Primeras Jornadas de Metodologia Aplicada a las Ciencias Históricas V. Paleografia y Archivistica. Santiago de Compostela 1975.

Pascual Martinez. L., "La Cancilleria de Enrique II de Castilla". Miscelanea Medieval Murciana. Universidad de Murcia, 1973, págs. 175-202; "Las Cancillerias de la Corte caste- 
Durante la década de los ochenta, a raíz en muchos casos de la celebración de reuniones cientificas sobre Diplomática hispana ${ }^{8}$, la investigación sobre la Cancilleria real castellana ha logrado un avance considerable, prueba de ello es la aparición de los trabajos de autores como M.I. Ostolaza Elizondo ${ }^{9}$, E. González Crespo ${ }^{10}$, D. Torres Sanz ", etc. En cualquier caso, para el siglo xv, el número de trabajos es aun muy reducido. Si contamos con algunas obras muy interesantes para el reinado de los Reyes Católicos ${ }^{12}$, pero para el de Enrique IV, por ejemplo, tenemos que conformarnos con la Colección Diplomática del monarca ${ }^{13}$ y con algunos estudios de interés, como los de A. Gómez Izquierdo ${ }^{14}$ y M. C.

Ilana durante el reinado de Enrique Il». Actas de las Primeras Jornadas de Metodologia Aplicada a las Ciencias Históricas V. Paleografía y Archivistica. Santiago de Compostela 1975: “Notas para un estudio de la Cancilleria castellana en el siglo xiv". Miscelánea Medieva! Murciana, vol. IV. Universidad de Murcia, 1978: "Notas para un estudio de la Canciilería castellana en el siglo xIv. La Cancillería de Pedro i (1350-1369)", Miscelánea Medieval Murciana. Universidad de Murcia, 1980: "La Cancilleria real castellana durante la regencia del infarite de Antequera". Miscelánea Medieval Murciana, vol. XI. Universidad de Murcia. 1984, págs. 177-236.

"Entre ellas podemos destacar las I Jornadas de Metodologia Aplicada a las Ciencias Históricas, cuyas actas se publicaron en Santiago de Compostela en 1975 y el I Congreso de Diplomática Pontificia y Real celebrado en Castellón en 1982, y publicado por la Sociedad Castellonense de cultura en el tomo 58 de su Boletín.

${ }^{9}$ Ostolaza Elizondo, M. I.. "La Cancillería y otros organismos de expedición de documentos durante el reinado de Alfonso XI". Anuario de Estudios Medievales, 16 (1986) págs. 147-225; «El Canciller Mayor de Castilla durante el reinado Alfonso XI". Anuario de Estudios medievales, 18 (1988). Homenaje a la memoria del profesor Emilio Sáez, vol. 2. Barcelona 1989, págs. 263-269; “Teoria y práctica de la función cancilleresca a través de los Ordenamientos de Cortes castellano-leonesas", Las Cortes de Castilla y León (1188- 1988), Actas de la III Etapa del Congreso Cientifico sobre la Historia de la Cortes de Castilla y León, vol. I. Valladolid 1990.

Gonzalez Crespo, E., "Organización de la Cancilleria castellana en la primera mitad del siglo Xiv", En la España Medieval V, 1984, págs. 447-470.

i1 Torpes Sanz, D., dedica al estudio de la Cancillería real castellana un capitulo de su obra La Administración Central castellana en la Baja Edad Media. Valladolid 1982.

- Martin Postigo, M. de la S., La Cancilleria castellana de los Reyes Católicos. Valladolid 1959; Abenia, C. y Baguena, R., Catálogo de una serie de cartas de los Reyes Católicos (14791502). Valencia 1945; Carande, R. y Carriazo, J. M. El tumbo de los Reyes Católicos del Concejo de Sevilla, 5 vols. Sevilla 1968-1971; Rodriguez VILLA, A., "Un cedulario de los Reyes Catóiicos", Rhi, 72 (1924); TORRE, A. DE LA. Documentos sobre relaciones internacionales de lcs Reyes Católicos. Barcelona 1949; Sanz Arizmend, C.. "Indice del tumbo de los Reyes Câtólicos (1474-1509)», Rhi, 72 (1924); Andrés, A., «Documentos originales de los Reyes Católicos en archivos particulares», RABM 1951

Memorias de Enrique IV de Castilla, ed. Real Academia de la Historia, vol. II. Madrid 1913. Conocemos también la existencia de la tesis doctoral inédita de PaLENzUELA GonzALEz, R. M. titulada La Cancilleria de Enrique IV de Castilla. Cargos y aportación documental (Universidad de Valladolid, 1971) en la que la autora registra 800 documentos

14 Gomez Izouieroo, A. Cargos de la Casa y Corte de Juan II. Cuadernos de la Cátedra de Paleografia y Diplomática, $V$. Universidad de Valladolid, 1958. 
Solana Villamor ${ }^{15}$ que, aunque centrados en los reinados de Juan II y Reyes Católicos, respectivamente, nos ofrecen algunas noticias sobre este periodo.

\section{LA ALTA NOBLEZA EN LA CANCILLERIA CASTELLANA DEL SIGLO XV}

\section{Los Cancilleres Mayores del Sello Mayor}

Desde la primera mitad del siglo XII el cargo de Canciller Mayor de León y de Castilla quedó vinculado a los más poderosos representantes del estamento eclesiástico: los arzobispos de Santiago y de Toledo, respectivamente. Dicha dualidad se mantuvo después de la unificación definitiva de Castilla y León conseguida por Fernando III. Durante la Baja Edad Media se observa un reparto tácito de dignidades entre ambos arzobispos: mientras el de Santiago prefiere titularse Capellán del Rey, el de Toledo figurara como Canciller Mayor de Castilla ${ }^{16}$.

Al frente de la Cancilleria se situabaan, por tanto, dos poderosos representantes del estamento eclesiástico que, aunque no desempeñaron personalmente sus funciones, sí aparecieron ejerciendo un control importante sobre dicho organismo ${ }^{17}$.

Al parecer fue en época de Fernando III cuando el oficio adquirió su configuración definitiva. El monarca consiguió que los dos prelados renunciasen a su derecho efectivo al cargo en favor del obispo de Osma. Desde entonces los arzobispos de Toledo conservaron el título de cancilleres mayores de Castilla como dignidad honorifica, producièndose la unificación del cargo acorde con la reunificación politica de la Corona ${ }^{18}$. Ambos arzobispos nombraban a un delegado para que en su nombre ejerciera las funciones de Canciller. Durante el reinado de Alfonso $X$, continuó la tradición de tener dos cancilleres honorificos en las personas de los arzobispos de Toledo y Santiago, sin embargo, mientras los arzobispos de Toledo usaron el titulo de "Chanceller de Castilla" durante todo el reinado, el Canciller del reino de León no figura en los documentos. Tampoco parece que se designase a ningún delegado para que desempeñase

\footnotetext{
15 Solana Villamor. M. C., Cargos de la Casa y Corte de los Reyes Católicos. Cuadernos de la Cátedra de Paleografia y Diplomática, Ill. Universidad de Valladolid, 1962.

"6anz Torres, D., Ob. cit., pág. 88.

1) lbidem, pág. 88.

18 Ibidem, págs. 88-89.
} 
sus funciones. Al parecer, èstas fueron asumidas por los notarios ${ }^{19}$. Sancho IV, sin embargo, mantuvo la división tradicional e incluso la aumentó con el "Chanceller de Andalucia", si bien reunió los tres titulos en una misma persona. Sus sucesores volverán a la antigua subdivisión, despareciendo el de Andalucia y desempeñando el ejercicio efectivo del cargo un funcionario que figura con el título de "Chancellarius domini regis", que generalmente era un personaje de la confianza del rey nombrado libremente por él ${ }^{20}$.

La legislación del rey Sabio nos da abundantes datos para el estudio de la figura del Canciller. Las Partidas y el Espéculo reglamentan sus funciones y marcan las cualidades que debia poseer quien desempeñara el cargo: "habia de ser vasallo del Rey y de buen linaje, destacando en lealtad, discreción e inteligencia, a más de poseer buena instrucción de letras" ${ }^{21}$

Las Partidas describen al Canciller como «el segundo Oficial de la Casa del Rey - después del Capellán-, de aquellos que tienen oficios de poridad. Ca bien assi como el Capellán es medianero entre Dios, e el Rey...lo es el Chanceler entre el, e los omes...E esto es, porque todas las cosas que ha de librar por carta de qual manera quier de sean, han de ser con su sabiduria: e el las deve ver ante que las sellen, por guardar, que non sean dados contra derecho, por manera que el Rey non reciba ende daño nin verguença. E si fallase, que alguna y avia, que non fuesse assi fecha, devela romper, o desatar con la peñola, a que digan en latin cancellare; e desta palabra tomo nome Chancilleria" ${ }^{22}$.

Uno de los textos más expresivos sobre la figura del Canciller Mayor es el que nos proporciona don Juan Manuel en el Libro de los Estados ${ }^{23}$ : el oficio de Canciller "es el mas honrado oficio y de mayor pro, que forzosamente ha de saber todo sobre la hacienda y las poridades del señor; debe tener los sellos y mandar hacer todas las cartas de cualquier clase, que todas las cartas que el señor vinieren o el señor enviase deben pasar por el canciller, pues una carta para ser tal debe ser sellada; por todo esto conviene que el canciller sea su privado y su Consejero; y por esto el canciller debe ser criado del señor".

Martin Postigo, M. de la S., La Cancilleria castellana de los Reyes Católicos, pág. 147.

${ }^{20}$ Sanchez Belda, L., "La Cancilleria castellana durante el reinado de Sancho IV...", pág. 177.

${ }^{21}$ Partidas, II, 9, 4, cit. por Martin Postigo, M. de la S., La Cancilleria castellana de los Reyes Católicos, págs. 146-147.

"Partidas, II 9, 4, ed. Códigos Españoles, II a V. Madrid 1948.

${ }^{23}$ DON JUAN MANUEL: Libro de los Estados, ed. por la Biblioteca de Autores Españoles, t. 51. Madrid 1952, cap. XCV, pág. 339. 
En ambos textos se atribuye al Canciller un control burocrático sobre la documentación real que en Partidas es además un control juridico desde el momento en que el Canciller se presenta como un miembro de pleno derecho de la Curia altomedieval ${ }^{24}$. No obstante, sabemos que en la práctica el Canciller ante un documento contrario a derecho debia limitarse a presentarlo ante el rey para que éste decidiera, sin posibilidad de asumir la cancelación automática que se le asigna en Partidas ${ }^{25}$.

El Canciller del Rey ostentó durante toda la Baja Edad Media una posición preeminente entre los oficiales reales, aunque dicha posición pareció diluirse durante el siglo $\times \mathrm{V}$, al cobrar personalidad y autonomía otros cargos de la Administración central ${ }^{26}$.

Por lo que respecta a las funciones del Canciller, según la Ordenanza de $1312^{27}$, que nos muestra el estado de la Cancilleria real y de otras oficinas de expedición de documentos a fines del reinado de Fernando IV, se ocupaba del tibramiento y la autentificación por sello de las cartas reales - no de todas desde que se constituyó la Cancillería de la Poridad-, del control de las mismas, de la custodia de los sellos reales y de la conservación de los libros. Además al Canciller competía la jefatura del personal que trabajaba a sus órdenes en la Cancilleria. De él dependia un escribano que tenía los sellos, otro que tenia los libros y otro que redactaba las cartas por orden suya ${ }^{28}$. Tambien se ocupaba de tomar juramento e investir a los escribanos y lugartenientes que actuaban con los oidores, alcaldes y notarios. Y, por úitimo, debía ocuparse del cobro de los aranceles de la expedición de cartas y de su eventual tasación ${ }^{29}$.

Las disposiciones de las Ordenanzas de 1312 nos explican la interrelación existente entre las funciones del Canciller del Rey y de los notarios mayores. Mientras éstos se ocupaban de ordenar y supervisar todo lo referente a la factura material de la documentación, aquél tiene como principal misión supervisar la colocación del sello, previa comprobación de que el documento no atentaba contra los intereses del rey ${ }^{30}$.

Sin embargo, en la práctica, la realidad obliga a admitir que el Canciller del Rey tendria un cargo más honorifico que efectivo, y así lo hace

${ }^{24}$ Con este carácter aparece en Especulo, II, 12, 2, cit. por TORRES SANZ, Ob. cit., pág. 91

${ }^{25}$ Cortes de Toro de 1371 en Cortes de los Antiguos Reinos de León y Castilla len adelante Cortes...), ed. Real Academia de la Historia. Madrid 1863, t. II, pág. 217.

26 Sanz TORres, D., Ob. cit., pág. 91.

27 Cortes..., t. I, págs. 197-221.

2 Ostolaza, M. I., "La Cancilleria y otros organismos...", pág. 155

is Torres Sanz, D., Ob. cit., pág. 93

${ }^{30}$ Ostolaza, M. I., "La Cancilleria y otros organismos...", pág. 157. 
suponer la alta jerarquía del personaje. Seguramente que su relación con la Cancillería era más estrecha que la mantenida por los arzobispos de Toledo, pero esto no nos permite suponer que se situara al frente de la misma. Posiblemente, su papel se limitaba a custodiar los sellos reales ${ }^{31}$. El cargo fue ejercido por lugartenientes cualificados y con una alta preparación jurídica.

Durante el siglo xv encontramos un Canciller Mayor del Sello Mayor, cargo que, como veremos, estuvo vinculado durante bastante tiempo a miembros del linaje de los Manrique, aunque indudablemente, continuaron figurando con el título honorífico los arzobispos de Toledo. Entre los lugartenientes que ejercieron sus funciones encontramos a personajes tales como Fernando López de Saldaña o el obispo de Cuenca, don Lope Barrientos, que aparecen en los documentos del reinado de Juan II como "tenedores de los sellos de la chancellería". Igualmente, durante el reinado de Enrique IV nos son conocidos los nombres de otros personajes a los que los documentos titulan cancilleres. Son éstos Juan de Uria, Alfonso Sánchez de Logroño, García y un tal Arriola ${ }^{32}$. En época de los Reyes Católicos tales funciones fueron ejercidas por el ya citado Alfonso Sánchez de Logroño y después por el doctor Antón Rodriguez de Lillo ${ }^{33}$.

El Canciller Mayor recibia a mediados del siglo xv 40.000 maravedies de ración y quitación, más 2.600 para pagar un oficial. Dichas cifras las conocemos a través de un asiento de contaduria conservado en el Archivo General de Simancas, atribuido por L. Suarez Fernández a la segunda mitad de $1447^{34}$.

Las funciones que se atribuyen al Canciller Mayor durante este periodo son la libranza de las cartas de privilegio y la aposición del sello. Lo primero era realizado juntamente con el Mayordomo Mayor y el Notario Mayor de los Privilegios, aunque en la práctica dicha función se llevaba a cabo en las Contadurias Mayores que contaban con unos funcionarios que firmaban por ellos como lugartenientes. La aposición del sello era realizada por selladores ${ }^{35}$. 178.

Sanchez Belda, L., "La Cancilleria castellana durante el reinado de Sancho IV...", pág.

Arribas Arranz, F., Sellos de placa de las cancillerias regias castellanas, págs. 110111 y $116-117$

33 Martin Postigo, M. de la S., La Cancilleria castellana de los Reyes Católicos, pág. 154.

${ }_{34}$ Archivo General de Simancas (en adelante A.G.S.). Mercedes y Privilegios (en adelante M. y P.), legajo 1, publ. por SuArez FERnANDEZ, :... "Un libro de asientos de Juan II". Hispania, XVII, 1957. 156-157.

Martin Postigo, M. de la S., La Cancilleria castellana de los Reyes Católicos, págs. 
A comienzos del reinado de Juan II el oficio de Canciller Mayor del Sello no estaba en manos de ningún noble, sino que su titular era el obispo Pablo de Santa Maria. Este hombre de origen judio, fue bautizado en Burgos el 21 de julio de 1390, y tras disolver su matrimonio judaico, abrazó el sacerdocio. Intelectual de gran cultura, Pablo de Santa Maria, destacó especialmente por su fervor religioso y su apostolado exacerbado, dedicaciones que alternó con la política ${ }^{36}$. En su carrera eclesiástica fueron hitos importantes su relación con Pedro de Luna, el Antipapa Benedicto XIII, de quien fue Consejero, y su nombramierito como obispo de Cartagena en 1403 y de Burgos en 1415. De su trayectoria politica cabe resaltar que fue Canciller del principe Juan y miembro del Consejo de Enrique III. Este monarca en su testamento otorgado en 1406 estableció que cuando vacase el cargo de Canciller Mayor del Seilo se le concediese al mencionado obispo ${ }^{37}$, lo que asi hizo su sucesor Juan $I^{38}$. Al parecer Pablo de Santa Maria tuvo dicho oficio hasta su muerte en 1435, aunque los últimos años de su vida permaneció retirado de la Corte en su diócesis.

Le sucedió en el cargo de Canciller Garci Fernández Manrique, I Conde de Castañeda. Nacido en el seno de una de las ramas secundarias del linaje Manrique, al haber sido su padre y homónimo, el Señor de Estar, un segundón, Garci Fernández dedicó todos sus esfuerzos a labrarse fortuna y porvenir por las vias entonces tradicionales, un ventajoso matrimonio con Aldonza de la Vega, con el que obtuvo el señorio de Aguilar y Castañeda, y el clientelismo político con uno de los infantes de Aragón, Enrique, del que fue Mayordomo Mayor ${ }^{39}$. Gracias a su relación personal con el Infante consiguió estar presente en algunos de los principales acontecimientos politicos del reinado de Juan II, introducirse en el Consejo Real ${ }^{40}, y$ obtener diversas mercedes como el título de Conde de

${ }^{36}$ Sobre este personaje puede consultarse la obra del Padre SERRano: Los conversos don Pablo de Santa Maria y don Alonso de Cartagena, Madrid 1942.

En una de las clausulas del testamento del rey dice: «E por quanto yo fize merçed del ofiçio de la chancelleria mayor del dicho prinçipe a don Pablo, obispo de Cartajena, e segund esta dicha ordenança, lo deva ser Pedro Lopes de Ayala, ques agora mi chançeller mayor. mando quel dicho oficio de chanceller mayor que lo aya el dicho Pedro Lopes segund que lo de mi tiene. Pero vacando el dicho ofiçio. quiero e es mi voluntad que aya el dicho ofiçio el dicho obispo....". Garcia de Santamaria, Alvar, Crónica de Juan II. Madrid 1982. pág. 37 .

${ }^{38}$ Perez de Guzman, Fernán, Generaciones y Semblanzas. Madrid 1965, pág. 89.

${ }^{39}$ Como tal se le cita en CARBullo de HuE.TE, P., Crónica del Halconero de Juan II (en adelante Halconero), ed. Juan de Mata Carrazo. Madrid 1946, pág. 26.

${ }^{40}$ Halconero, pág. 32. 
Castañeda ${ }^{41}$, aunque también es cierto que cuando habia logrado cierto estatus socio-politico y tras varios años de seguir la causa del Infante don Enrique, terminó abandonándole en 1429 y poniéndose al servicio de Juan II, que le recompensaría con ciertos bienes: la villa de $\mathrm{Cea}^{42}$, la de Galisteo ${ }^{43}$, y el cargo de Canciller Mayor. Aunque desconocemos la fecha exacta de su nombramiento para este oficio, todo parece indicar que fue en 1435, año en el que falleció el hasta entonces Canciller don Pablo de Santa Maria ${ }^{44}$. Desde ese momento y a lo largo del siglo xv el cargo de Canciller Mayor se vincularia a esta importante rama del linaje Manrique.

Garci Fernández murió en Alcalá de Henares el 22 de mayo de 1436. En su testamento otorgado el día 16, dejaba a su primogénito Juan Manrique, por mayorazgo ${ }^{45}$, sus principales bienes, asi como el titulo de Conde de Castañeda y el oficio de Canciller Mayor, aunque formalmente solicitaba al rey que le concediese dicho cargo, petición que también hacia extensible al Condestable don Álvaro de Luna. En la misma claúsula testamentaria rogaba a su hijo que entregase el oficio al doctor Juan Hernández de Soñer, que lo había tenido hasta entonces, ordenándole que no se 10 quitase ${ }^{46}$.

Muerto Garci Fernández, el rey confirmó a su hijo Juan Manrique el título de Conde de Castañeda y le otorgó el oficio de Canciller Mayor,

${ }^{4}$ El 28 de octubre de 1420 en Talavera, Juan II concedia la tenencia de Castañeda con su tierra, vasallos, términos y jurisdicción civil y criminal. Archivo de los Condes de Castañeda, m." 124. Publicado por Martin de Sandoval, Evaristo y Travesedo y Colon de Carvajal, Carmen, en "Garci Fernández Manrique, I Conde de Castañeda, 1420-1436", Altamira, 1975. Ese mismo año el rey debió hacerle Conde de Castañeda. Perrez de GuzMan, Fernán, Crónica de Juan II, ed. B.A.E. 68. Madrid 1953, pág. 388.

4. Salazar y Castro, L., Historia Genealógica de la Casa de Lara (en adelante Casa de Lara). Madrid 1696, t. I, pág. 496.

4: Real Academia de la Historia (en adelante R.A.H.). Colección Salazar y Castro (en adelante Salazar). M-123, iol. $8 \mathrm{v}$ a 12 . Privilegio rodado de Juan II por el que confirma un albalá dado en Roa el 4 de marzo de 1429 por el que donó a Garci Fernández Manrique. Ja vilia de Galisteo. Otorgado en Ciudad Rodrigo, el 2 de octubre de 1432. Publicado por $S_{A}$ LAZAR y CASTRO, L.. Pruebas históricas de la Casa de Lara (en adelante Pruebas). Madrid 1696, págs. 81-84 Halconero, pág. 52 y BARRIEnTos, Lope de. Refundición de la Crónica de Halconero (en adelante Refundición), ed. Juan de Mata Carriazo. Madrid 1946, pàg. 89.

${ }^{4}$ Vid. Arribas Arranz, F., Sellos de placa de las Cancillerias regias castellanas, pág. 110 .

4 Por albalá del 22 de agosto de 1432, Juan II le habia autorizado para disponer y distribuir sus bienes entre sus hijos. R.A.H. Salazar. M-123, fol. $74 \mathrm{v}$ a $77 \mathrm{~V}$.

th R.A.H. Salázar, M-123, fol 1-8. Documento citado por Montero Tejada, Rosa M. ". en "Los Manrique en las instituciones de gobierno de la monarquia castellana. (1379-1516)", en La Peninsula lbérica en la Era de los Descubrimientos (1391-1492). III Jornadas Hispano-portuguesas de Historia Medieval, en prensa. 
cumpliendo asi la voluntad de su padre ${ }^{4 /}$. Las primeras noticias de la vida politica de Juan Manrique se inician con su intervención en 1431 en la guerra de Granada ${ }^{48}$. Tras el fallecimiento de su progenitor, siguió durante algún tiempo el partido de los grandes que apoyaban a los Infantes de Aragón, pero abandonó pronto dicha causa y volvió al servicio del rey, quien en premio a su lealtad le concedió la villa de Cea -que ya habia otorgado a su padre pero sin efecto-, además de la merced en 1444 de los cuatro valles de Yguña, Rionansa, San Vicente y Toranzo en la Asturias de Santillana, con la jurisdicción civil y criminal ${ }^{49}$. Durante el resto del reinado permaneció fiel al monarca.

Ya con Enrique IV, Juan Manrique continuó teniendo el cargo de Canciller Mayor, pues como tal confirma en diversos privilegios y se le menciona entre los asistentes a las Cortes de $1455^{\text {bo }}$. Nombrado por dicho monarca Capitán General de la Frontera de Jaén con el mando de dos mil lanzas, fue apresado en 1456 por los granadinos, y no seria liberado hasta después de 17 meses de cautiverio, una vez pagado por su esposa, la Condesa Maria Enríquez, la mitad del rescate exigido, 60.000 doblas de la banda, y de dejar como rehén a su hijo Garci Fernández Manrique, primogénito del Conde ${ }^{51}$.

En 1465 Juan Manrique se adhirió al partido nobiliario que proclamó rey al Infante Alfonso, hermano de Enrique IV, aunque al parecer no estuvo presente en la "Farsa de Ávila», donde se procedió al destronamiento del monarca ${ }^{52}$. Sin embargo, abandonó la causa del Infante en 1467, indignado, según Alonso de Palencia, porque Alfonso habia entregado la dignidad de Maestre de Santiago al Marqués de Villena, Juan Pacheco, que él consideraba pertenecia por derecho a su hermano Gabriel Manri-

Halconero. pág. 229: Refundición. pág. 202. En 1436 el Rey le concedió los 40.000 maravedies de quitación que tenia su padre con el oficio de Canciller Mayor. y 2.600 maravedies para un oficial. A.G.S. Quitaciones de Corte, (en adelante. Q. de C.). legajo 1. fol. 155 Publicado por Arribas Arranz. F., en Sellos de placa de las cancillerias regias castellanas. pág. 213

ah Pérez de Guzman, F.. Crónica de Juan II, pág. 499.

4: Salazar y Castro. L., Casa de Lara, t. I, pág. 514. Merced en virtud de un albalá del rey dado el 28 de agosto de 1444 .

Ibidem. pág. 517. Cortes., III. pág. 675. El 31 de septiembre de 1455 Enrique IV le confirmaba el oficio de Canciller Mayor, con la quitación y los salarios correspondientes. A.G.S. Q. de C. legajo 3, fol. 572 .

"Valera, Diego de, Memorial de Diversas Hazañas, ed. de Juan de Mata Carriazo. Madrid 1941, págs. 37 a 39: Hechos del Condestable don Miguel Lucas de iranzo, ed. Juan de Mata Carriazo. Madrid 1940. pág. 68; y Enriouez DEl CAstillo, Diego, Crónica del Rey Enrique IV. B.A.E. t. 70. Madrid 1953, págs. 108-109.

Valera, Diego de, Ob. cit. págs. 101-102; Palencia, Alonso de. Crónica de Enrique IV. B.A.E. 257-258. Madrid 1973-1975, pag. 171 
que, Conde de Osorno y Comendador Mayor de Castilla en dicha Orden ${ }^{53}$. Por este motivo en la batalla de Olmedo participó su hijo Garcia con 70 caballos al lado de Enrique IV, permaneciendo ambos fieles a este monarca hasta el final de su reinado. Cabe preguntarse qué sucedió con el oficio de Canciller Mayor durante los dos años que Juan Manrique siguió la parcialidad de Alfonso. Probablemente el rey le cesó en el cargo como castigo a su deslealtad, aunque el Conde de Castañeda no sufrió menoscabo pues el Infante Alfonso le tomó también como su Canciller Mayor ${ }^{54}$. Juan Manrique debió gozar de dicho oficio hasta el abandono de la "Corte» alfonsina, volviendo luego a desempeñarlo con Enrique IV tras ser perdonado.

El Conde de Castañeda prestó juramento a los Reyes Católicos a su llegada al trono y los monarcas le confirmaron el cargo de Canciller Mayor del Sello de plomo ${ }^{55}$. Sin embargo, pronto renunciaria el oficio en su hijo Garci Fernández Maníique, que fue nombrado Canciller por los reyes el 15 de abril de 1475, aunque Juan se reservaba los derechos y quitaciones inherentes al cargo ${ }^{56}$. En nombre de Garcia, tomó posesión del oficio en la Audiencia de Valladolid, el 30 de abril de 1479, el licenciado Alonso Sánchez de Logroño, que fue recibido para usar y ejercer el oficio de Canciller, como lugarteniente del titular, según ya lo había desempeñado con su padre Juan Manrique ${ }^{57}$. La prohibición de los monarcas de renunciar cargos en otras personas con reservas de quitación en las Cortes de Toledo de 1480, obligó al Conde de Castañeda a dejar todos los derechos pertenecientes al oficio de Canciller a su hijo, quien tras volver a prestar juramento y pleito homenaje, recibió el arca de los sellos con las llaves, y tomó por lugarteniente al doctor Antón Rodriguez de Lillo, oidor de la Audiencia y miembro del Consejo Real, que fue recibido en dicho cargo en lugar de Alfonso Sánchez de Logroño ${ }^{38}$.

5: Palencla, Alonso de, Ibidem, pág. 224.

${ }^{54}$ En una carta dada en Villanueva, el 8 de junio de 1465 , el Infante Alfonso se dirige a Juan Manrique, diciendo «...a vos don Juan Manrique, Conde de Castañeda mi canciller mayor e del mi consejo". R.A.H. Sign. 9-30-7. Publicado por Martinez Marina, Francisco, Teoria de las Cortes o Grandes Juntas Nacionales de los Reinos de León y Castilla, III vols. Madrid 1913, págs. 454-457. Citado por Morales Muñiz, M. ${ }^{a}$ Dolores Carmen. Alfonso de Ávila, rey de Castilla. Ávila 1988, pág. 338.

Sulgar, Fernando del, Crónica de los Reyes Católicos. B.A.E 70. Madrid 1953, pág. 254.

A.G.S. Q. de C. legajo 20, fol. Garcia Fernández Manrique. Publicado por ArRIBAS Arranz, F., en Sellos de placa de las cancillerias regias castellanas, pág. 197

"Martin Postigo, M. de la S., La Cancilleria castellana de los Reyes Católicos, pág. 153. Alfonso Sánchez de Logroño figuraba ya como Canciller en un libramiento por oidor de la Audiencia del rey dado el 29 de agosto de 1459. A.G.S. Q. de C. legajo 2, fol. 153.

so Martin Postigo, M. de la S., La Cancillería casiellana de los Reyes Católicos, págs. $152-154$. 
Garcia Fernández Manrique, III Conde de Castañeda, fue hijo de Catalina Enriquez de Ribera, dama que se criaba en la casa de los condes. con los que estaba emparentada ${ }^{\text {b9 }}$. Al ser estéril la condesa Doña Mencía Enriquez, Juan Manrique solicitó al monarca que legitimase a Garcia para que pudiese sucederle en sus estados y en sus oficios, lo que asi hizo Juan II en $1453^{60}$.

La falta de noticias sobre la trayectoria política de Garcia Fernández, parece indicar que llevó una vida bastante retirada en sus estados, alejado de los acontecimientos políticos y cortesanos hasta 1506, año en el que le encontramos entre los nobles que acudieron a recibir a Felipe y a Juana a la Coruña. Su presencia en dicho recibimiento indica su adhesión a los nuevos monarcas y su oposición a la gobernación de Fernando el Católico, opción política que habia seguido, igualmente, su poderoso pariente, el Duque de Nájera ${ }^{61}$. Ese mismo año, en el mes de junio, le sorprendió la muerte en Monterrey (Galicia), cuando acompañaba a los reyes en su viaje hacia Castilla ${ }^{62}$. Su hijo Luis Fernández Manrique, IV Conde de Castañeda y II Marqués de Aguilar le sucedió en sus títulos y señorios, asi como en el oficio de Canciller Mayor, cargo del que le hizo merced en julio de 1506 , el rey Felipe ${ }^{63}$, y que le confirmaria Fernando el Católico a su regreso a Castilla tras la prematura muerte del mencionado monarca ${ }^{64}$.

\section{Los Cancilleres Mayores de la Poridad}

Es en la obra legislativa de Alfonso $X$ donde encontramos las primeras referencias sobre las "cartas de poridad": "Cancelleria es lugar do deven aduzir todas las cartas para sellar, e aquellos que lo ovieren de ver, devenlas catar, e las que non fueren bien fechas, devenlas romper, e que-

59 Salazar y Castro, L., Casa de Lara, t. I, pág. 522

60 Documento dado en Tordesillas el 5 de enero de 1453. R.A.H. Salazar, M-5, fols. 277 y $277 v$. Publicado por Salazar y Castro, L., en Pruebas, pág. 96. Esta legitimación fue confirmada por Fernando el Católico en Cáceres el 19 de abril de 1479. Archivo Histórico Nacional (en adelante A.H.N), Osuna, legajo 1819, n.", 5 y por su mujer Isabel el 15 de junio de 1480. A.G.S. Registro General del Sello (en adelante R.G.S), fol. 25.

'ZuRITA, Jerónimo, Los cinco libros postreros de don Fernando el Católico. Zaragoza 1680, libro VI, pág. 53.

62 Galindez de Carvajal, Lorenzo, Anales breves del reinado de los Reyes Católicos, B.A.E. 70. Madrid 1953, pág. 555.

${ }^{63}$ A.G.S. R.G.S, 12 de julio de 1506. Valladolid. Publicado por Arribas Arranz, F., Sellos de placa de las cancillerias regias castellanas, págs. 215-217. 133.

64 Zurita, Jerónimo, Los cinco libros postreros de don Fernando el Católico, libro VII. pág. 
brantar; e las que fueren fechas derechamente, devenlas mandar sellar. E por esto la llaman Cancelleria, porque en ella se deven quebrantar, e cancellar las cartas que fueren mal fechas: e lo que deven guardar, es esto: que non tomen cartas de mano de otro ome, si non de Escrivano o de Portero del Rey. E las cartas de poridad, que dieren a qualquier de los que estuvieren en la Cancelleria, por mandado del Rey o por mano de alguno de los notarios, dezimos que deve guardar aquel a quien las diesse. E otrosí que no sellen las cartas ante que sean registradas" ${ }^{65}$.

Estas cartas estaban validadas con el sello secreto o de la poridad, de ahi su nombre, y se diferenciaban de las validadas con el sello mayor por su contenido y por su estrecha relación con el rey. Respecto a esto, no obstante, existen distintas opiniones entre los autores que han abordado el tema. Mientras algunos consideran que los documentos sellados con el sello de la poridad carecian de obligatoriedad oficial, salvo manifiesta voluntad en contrario del rey ${ }^{66}$, otros se inclinan a pensar que no carecian de tal obligatoriedad, sino que, en general, eran aquellas cartas que no tenian caracter judicial ni suponian el ejercicio del derecho real de gracia ${ }^{67}$.

La existencia de la Cancilleria de la Poridad se deja entrever por primera vez durante el reinado de Alfonso $X$, pudiendo demostrarse su existencia sin ningún tipo de dudas en el de su hijo Sancho IV. La organización de esta Cancillería se explica por el aumento de los asuntos privados del monarca, que eran despachados en un principio por un secretario de cámara ${ }^{68}$. Algunos autores han querido ver el origen de esta Cancilleria

is Partidas, III, 2.0.6.

* Esta es la opinión, por ejemplo de Pascual Martínez, L., entre otros. Véase "Las Cancillerias de la Corte castellana durante el reinado de Enrique II", pág. 262, cit. en nota 7. El autor dice textualmente: "En realidad la única nota que las diferenciaba de la cancilleria mayor era la validez oficial de los diplomas de ellas emanados. Sólo los sellados con el sello mayor obligan oficialmente a su cumplimiento" (pág. 261) y "Cuando ocurría al rey tener que dar una orden que debia ser cumplida y no estaba con él la Cancillería mayor, entonces aclara en el mismo documento cómo se ha de cumplir lo que en él se dice, aunque vaya sellado con el sello de la puridad».

${ }^{6}$ Esta es la opinión de TORres SANz. D., véase: Ob. cit, págs. 93-94. El autor dice textualrnente: "Desde el punto de vista de su contenido serian aquellas cartas que, en general, no tuvieran caracter judicial ni supusieran el ejercicio del derecho real de gracia, que estaba intimamente relacionado con el concepto medieval de justicia; es decir, "cartas de poridad" serian las que, de acuerdo con la ampliación funcional propia de la monarquia bajomedieval, habian surgido precisamente para cubrir la actividad de gobierno que rebasaba o no podia subsimirse en la noción de justicia, la actividad regia dinámica y discrecional frente a una aplicación relativamente automática de los principios jurídicos y sociales tradicionales representados por las otras" cartas.

G. Martin Postigo, M. de la S. La Cancilleria castellana de los Reyes Católicos, págs 149. 
en intima conexión con la existencia de esta secretaria de cámara que atendia los asuntos personales del rey ${ }^{69}$. El sello de la poridad era custodiado por un Canciller especifico denominado "sigilli secreti domini regis cancellarius" que acompañaba al rey en todos sus desplazamientos, de manera que nunca se echara en falta el sello de la poridad.

Conocemos varias cartas reales que fueron selladas con el sello secreto por no encontrarse con el rey los otros sellos ${ }^{70}$. Esto ha llevado a pensar a la mayoria de los autores que el rey se sirvió de la Cancilleria Secreta para todos sus negocios, aunque no fueran privados. En las Cortes de Toro de 1369 y 1371 se legisla el proceder a seguir con aquellos diplomas que se sellaban con el sello de la poridad: "Otrosi ordenamos y mandamos que por el nuestro sello de la poridat non sellen cartas de perdón nin de justiçia nin de merçedes, nin cartas foreras, mas que se sellen por el nuestro sello mayor; e si se sellaren por el nuestro sello de la poridat, que non valan e los oficçiales de la nuestra corte e de las çibdades e villas e lugares del nuestro señorio que las non cunplan" ${ }^{71}$. Quedaban excluidos de ser expedidos por la Cancilleria de la Poridad todos aquellos documentos que requerian especiales solemnidades en su factura y la aposición del sello mayor.

Las funciones del Canciller de la Poridad, muy similares a las del Canciller Mayor, eran la custodia del sello secreto, la responsabilidad de su correcta utilización y el control del personal de su Cancilleria. Su proximidad al monarca, caracteristica esencial del cargo, que le convertia en colaborador inmediato de éste, se fue debilitando con el paso del tiempo, hasta el punto de que en el siglo xv se irá acentuando su caracter burócrático, al tiempo que otros oficiales, los secretarios, van ocupando los puestos de confianza junto al rey ${ }^{72}$.

A lo largo de esta centuria el cargo de Canciller Mayor de la Poridad fue ocupado por varios personajes entre los que encontramos a individuos de muy distinta procedencia. Algunos fueron, como veremos, miembros de la más alta aristocracia castellana, como es el caso de los Mendoza; otros, como Rodrigo de Villacorta, tuvieron una procedencia social más modesta, y, entre ellos, no faltaron los eclesiásticos como don San-

69 SÁnchez Belda, L., "La Cancilleria castellana durante el reinado de Sancho IV", págs. 220-221

${ }^{10}$ «Et porque los otros mios sellos non eran aqui conmigo, mande seellar esta carta con el mio seello de la poridat". A.H.N. Clero. legajo 88, 130, 723, 5, cit en Ibidem, págs. 221

${ }^{1}$ Cortes..., II, 1369, págs. 170 y 195, cit. por Pascual Martinez, L., "Las Cancillerias de la Corte castellana durante el reinado de Enrique II", pág. 262

${ }^{72}$ Torres Sanz, D., Ob. cit., pág. 96 
cho de Rojas, obispo de Palencia o don Martín Fernández de Vilches que fue también Capellán y secretario del rey y llegó a ser obispo de Ávila. En especial, durante los años de reinado de Enrique IV el cargo no recayó en miembros de la alta nobleza castellana, pues este monarca prefirió rodearse de simples hidalgos, nobles sin títulos o incluso legistas, a los que elevó de un modo sistemático. Su clara desconfianza hacia la nobleza le hizo tolerarla en los puestos más altos únicamente en aquellos casos en que era necesario ${ }^{73}$. Bajo su protección hicieron carrera personajes como Martin Fernández de Vilches o Miguel Lucas de Iranzo, ambos, como veremos, cancilleres de la poridad.

El primer personaje que aparece como Canciller Mayor de la Poridad en el reinado de Juan II es Juan Martínez, que ya lo era en el reinado anterior. Por desgracia, no tenemos datos suficientes que nos permitan reconstruir su trayectoria y tampoco tenemos noticia de su nombramiento o de la fecha en que dejó de ejercer el cargo ${ }^{74}$. Lo que si sabemos es que ya en 1415 figuraba como Canciller de la Poridad don Sancho de Rojas, ya que asi consta en una merced conservada en Simancas ${ }^{75}$.

Don Sancho de Rojas fue hijo de Juan Martínez de Rojas, señor de Monzón y de doña Mencia de Leiva. Vivió entre los años 1382 y 1432 y llegó a ocupar cargos tan importantes como los de Consejero real o Canciller Mayor de la Poridad. Sin embargo, lo más destacado de su trayectoria fue, sin duda, su brillante carrera eclesiástica, pues, tras haber sido obispo de Astorga y Palencia, fue elevado al arzobispado de Toledo por Benedicto XIII en 1415. Ocupó un papel político importante durante la minoria de edad de Juan II, en especial desde el nombramiento del Infante de Antequera como rey de Aragón, pues se le encomendó el gobierno de las provincias del Norte, a fin de evitar las alteraciones de los magnates turbulentos. Igualmente, gozó de gran influencia en la Corte, hasta el punto de que, según el cronista de su reinado, a su influjo se debió la unión de Juan II y doña María, hermana de los Infantes de Aragón, a los que desposó en 1418, contra la opinión de la mayoria del Consejo de Regencia que queria casar al rey con doña Leonor de Portugal ${ }^{76}$. Durante el reinado de Juan $\|$ desempeñó importantes misiones politicas al servicio del rey como fueron sus actuaciones como embajador a Navarra en 1429

\footnotetext{
13 SuÁrez Fernández, L., "Los Trastámara de Castilla y Aragón en el siglo xV" en Historia de España, dir. por Menendez PIDAL, R., t. XV, pág. 222

${ }^{\prime 4}$ Únicamente hemos encontrado a Juan Martinez como Canciller Mayor de la Poridad en Cortes..., t. III, págs. 1-4.

is A.G.S. Patronato Real, leg. 58, fol. 45, cit. por Arribas Arranz, F., Sellos de placa de las Cancillerias regias castellanas, págs. 111 y 122

"Sérez de Guzman, Fernán, Crónica de Juan /I, pág. 37
} 
o a Inglaterra un año después. Murió en Alcalá de Henares el 21 de octubre de 1432.

A Sancho de Rojas le sucedió en el cargo de Canciller Mayor de la Poridad su sobrino Diego Gómez de Sandoval, hijo de Fernán González de Sandoval y de Inés de Rojas, pues como tal figura en diversas fuentes del periodo. Desgraciadamente, no conocemos la fecha exacta del nombramiento, pero ya en 1430, dos años antes de la muerte del arzobispo de Toledo, figura como tal ${ }^{7 /}$. Al quedar huérfano de padre cuando tenia pocos años, fue enviado por su madre a la casa de su tio don Sancho de Rojas, muy afecto, como hemos visto a don Fernando de Antequera, el cual decidió nombrarle paje suyo. Unos años después se convirtió también en ayo y educador de su hijo el infante don Juan, futuro rey de $\mathrm{Na}$ varra y de Aragón. En 1411 fue nombrado Adelantado Mayor de Castilia ${ }^{78}$. Acompañó al Infante de Antequera en sus campañas contra el reino de Granada y éste, para recompensarle por todos sus servicios y quizá también para contar en Castilla con un aliado fiel, le concedió la villa burgalesa de Lerma, tras haber sido coronado rey de Aragón en 1412. A partir de este momento don Diego tuvo un único objetivo: formar un linaje propio y elevarlo al rango social más elevado ${ }^{79}$. Para ello contaba con el apòyo de los Infantes de Aragón, a los que permaneció vinculado durante toda su vida, y de su tío don Sancho de Rojas ${ }^{80}$.

En el entrentamiento entre el infante don Enrique y su hermano Juan, don Diego y su tio apoyaron al segundo, y tras la caida del infante don Enrique, que fracasó en sus pretensiones de hacerse con el poder, don Diego fue recompensado con la villa de Osorno. Poco tiempo después Juan II le concedió el título de Conde de Castro, del que formaban parte trece villas que habian pertenecido al rey de Navarra, y que junto con Lerma, Cea y Gumiel formarian un mayorazgo ${ }^{81}$.

El Adelantado Diego Gómez de Sandoval se vio envuelto en la pugna entre los Infantes de Aragón y don Alvaro de Luna, siempre fiel a don Juan de Navarra. Por este motivo en 1430 fue llamado a comparecer en la Corte y a abandonar el partido del rey de Navarra. Tras su negativa a

Halconero, págs. $78-79$

'Confirma como Adelantado Mayor de Castilla en un Privilegio Rodado fechado el 11 de marzo de 1411, A.H.N. Osuna, 10-15, cit. por Perez Bustamante, R., El Gobierno y la Administración de los Reinos de la Corona de Castilla (1230-1474). Madrid 1976, pág. 321, nota 163.

${ }^{79}$ Franco Silva, A., "El Jinaje Sandoval y el señorío de Lerma en el siglo xv». Actas del I Congreso de Historia de Castilla y León. I. Edad Media. Burgos 1983, págs. 134-135

to lbidem, pág. 136

"R.A.H. Salazar, F-7, fol. 23-29v; Franco Silva, A., "El linaje Sandoval...", págs. 138-139. 
presentarse en la Corte se inició un proceso por el que fue condenado, lo que motivó su huida al reino de Aragón ${ }^{82}$.

La derrota de los infantes de Aragón supuso para don Diego Gómez de Sandoval la pérdida de sus señoríos. En compensación Alfonso $V$ de Aragón le concedió varias villas en Valencia y el condado de Denia. En 1436, tras firmarse la paz entre Juan II de Castilla y los infantes de Aragón sus señorios fueron embargados por la Corona, aunque los recuperó tres años después ${ }^{83}$. Tras la derrota de los aragoneses en la batalla de Olmedo, en la que participó junto a Juan II de Navarra, fue hecho prisionero y se le privó de todos sus oficios. El 29 de agosto de 1445 el rey Juan II concedió el cargo de Canciller Mayor de la Poridad a Juan de Luna, hijo del Condestable don Alvaro de Luna ${ }^{84}$. Sin embargo, al año siguiente, tras el acuerdo de Astudillo, todos los nobles que participaron en la batalla del lado de los Infantes fueron perdonados. Don Diego recuperó el título de Conde de Castro con algunos de sus antiguos señorios y es posible que también el cargo de Canciller Mayor de la Poridad, pues en un libro de asientos de Juan II, fechado en la segunda mitad de 1447 , figura como utenedor de los sellos de la poridad con 12.000 maravedies" " 55 . Don Diego de Sandoval murió en 1455 sin ver recuperados sus señorios salvo Lerma.

A finales del reinado de Juan 11 el cargo de Canciller de la Poridad recayó en Rodrigo de Villacorta, que ocupó el oficio hasta la muerte del monarca el 22 de julio de 1454, y que disfrutó de 12.000 maravedies anuales de quitación y 80 más diarios de ración por el mismo ${ }^{86}$.

Para sustituir a Rodrigo de Villacorta, Enrique IV nombró Canciller de la Poridad a comienzos de su reinado a Martín Fernández de Vilches que, al igual que el anterior, no perteneció a ningún linaje de la alta nobleza castellana, aunque fue un personaje de relieve en la Corte de Enrique IV, como se desprende del desempeño de cargos tan importantes y próximos

\footnotetext{
82 SuÁrez Fernández, L., Nobleza y Monarquia. Puntos de vista sobre la historia castellana del siglo XV. Valladolid 1959, pág. 99 y 105

83 Franco SILva, A., "El linaje Sandoval...", págs. 139-140.

${ }^{84}$ El documento dice textualmente: «...por quanto yo prive y por la presente privo del dicho oficio al conde Diego Gómez de Sandoval que hasta aqui por mi lo tenía porque el 10 perdio con todos sus otros oficios y bienes por las cosas por el cometidas en mi deservicio y contra el bien de la cosa pública de mis reinos y especialmente porque se armo y puso y vino en la batalla contra mi y contra el principe don Enrique... y contra el mi pendon rea de las mis armas en favor del rey don Juan de Navarra y del infante Enrique su hermano y de otros suys secuaces". R.A.H. Salazar, M-9, fol. 329-329v.

at Suarez Fernandez, L., "Un libro de asientos de Juan II», pág. 338-340

${ }^{86}$ A.G.S. M. y P., legajo 13 , fol. 81 , con fecha 28 de febrero de 1454 ; A.G.S. Q. de C. legajo 4, fol. Martín Fernández de Vilches.
} 
al monarca como los de Capellán y secretario del rey. También fue Consejeró real y obispo de Avila. Recibió por dicho oficio de Canciller la misma ración y quitación que Villacorta había recibido de Juan 11 , con efectos desde el día del fallecimiento de éste ${ }^{87}$.

En 1456 Enrique IV designó un nuevo Canciller de la Poridad en sustitución del obispo de Ávila ${ }^{88}$. Se trataba de don Miguel Lucas de Iranzo, que muy pronto sería nombrado también Condestable de Castilla.

La mejor fuente con que contamos para reconstruir la trayectoria de don Miguel Lucas de Iranzo es, sin duda, la crónica titulada Hechos del Condestable don Miguel Lucas de Iranzo ${ }^{89}$, atribuida a Pedro de Escavias, que nos ofrece un minucioso relato de la vida de este personaje desde marzo de 1458, en que recibió los títulos de barón, Conde y Condestable de Castilla, hasta diciembre de 1471, diecisiete meses antes de su muerte.

Las otras Crónicas de su tiempo le dedican menos atención y le tratan, en general, como personaje de dudosa reputación.

Entre las peores consideraciones que se hicieron sobre su persona hay que destacar la de Alonso de Palencia, sin duda el que peor le trata, que habla de su "ínfima cuna" y de su ufamiliaridad de adolescente con el rey" " ${ }^{90}$ y la de Diego de Valera, que dice de él que era "hombre de poco estado y linaje" y le llama "cruel y tirano" y «hombre que siempre favorecia a los populares" ${ }^{91 .}$

Como es bien sabido, don Miguel Lucas de Iranzo nació en Belmonte, en el seno de una familia modesta, pues, al parecer, su padre, Alonso Alvarez de Iranzo, era labrador. Su carrera política se inició gracias a la ayuda del marqués de Villena que le colocó, en vida de Juan II,como paje del principe heredero. No tardó Iranzo en ganarse la confianza de don Enrique, quièn, tras haberle hecho su halconero mayor, le nombró corregidor de la ciudad de Baeza, según consta en el libro del Cabildo de la misma ${ }^{92}$.

\footnotetext{
${ }^{8}$ A.G.S. Q. de C., legajo 4, fol. 150, cit. en Arribas Arranz, F., Sellos de placa de las Cancillerias regias castellanas, pág. 116 .

${ }^{88}$ Albalá de 20 de julio de 1456. A.G.S. Q. de C., legajo 4, fols 148-151; Memorias de Enrique $N$, doc. XLIX

"99 Véase nota 52.

${ }^{90}$ Palencia, Alonso de Crónica de Enrique IV, edición de Paz y Meliá. Madrid 1904-1908, libro III, cap. 3, cit. en el estudio preliminar realizado por J. de Mata Carriazo en Hechos..., pág. XXXVII.

${ }_{91}$ Valera, Diego de, Ob. cit., págs. 22, 23, 25, 37, 48, 51, 102, 108, 120, 206, 207 y 243-245.

${ }_{92}$ No hay que olvidar que don Enrique tenia las ciudades y villas del reino de Jaén en principado. Véase el estudio preliminar de J. de Mata Carriazo, en Hechos..., XXXIX.
} 
La subida al trono de Enrique IV aceleró su encumbramiento y en muy pocos años consiguió alcanzar un puesto destacado en la Corte y una posición privilegiada. Entre 1454 y 1455 lo encontramos ya como alcalde mayor de Baeza, alcaide de Alcalá la Real ${ }^{93}$, alcaide de Jaén y Consejero real. Además, el 12 de junio de 1455 don Enrique le armó caballero y le hizo noble, señalándole las armas que debia llevar en su escudo ${ }^{94}$. El 20 de julio de 1456 recibió el cargo de Canciller Mayor de la Poridad con 80 maravedies diarios de ración y 12.000 de quitación anual que le sumaban al año un total de 28.800 maravedies ${ }^{95}$.

Todo ello hizo que la posición de Iranzo fuera pronto envidiada por los dirigentes de la alta nobleza y, en especial, por quien le habia ayudado a entrar al servicio del rey, el marqués de Villena. Su enemistad con don Juan Pacheco se vio acrecentada además por la cuestión del maestrazgo de Santiago, tan deseado por éste, y al que Iranzo aspiraba. Bien conocidos son los acontecimientos posteriores, el enfrentamiento de ambos partidos y la permanerite lealtad que don Miguel Lucas mostró al monarca. Tuvo oportunidad de alcanzar más altos puestos, pero prefirió renunciar a la lucha politica y alejarse de la Corte.

El 25 de marzo de 1458 había recibido del monarca los titulos de barón, Conde y Condestable de Castilla, vacante este último desde la muerte de don Álvaro de Luna ${ }^{96}$.

En 1473 fue nombrado Canciller Mayor de la Poridad para sustituir a Iranzo don Pedro González de Mendoza, quinto hijo del I Marqués de Santillana y de doña Catalina Suarez de Figueroa ${ }^{97}$, cuya trayectoria es bien conocida ${ }^{98}$. Desde muy joven inició una brillante carrera eclesiástica que

\footnotetext{
${ }_{93}$ Miguel Lucas de Iranzo fue recibido como alcalde mayor de Baeza el 8 de agosto de 1454 y ese mısmo año recibió la alcaldia de Alcalá la Real, poniendo en su lugar como alcaide a un padrastro suyo. Ibidem, pág. $X X X \mid X$.

${ }^{y 4}$ Vid. Memorias de Enrique IV, ed. Real Academia de la Historia. Madrid 1913, t. II, doc. XLIX, pág. 141

${ }_{95}$ A.G.S. Q. de C., legajo 4, fol 148-151.

${ }^{96}$ A.G.S. Q. de C, legajo 4, fol. 150. Se le concede la misma quitacion que del rey don Juan tenia don Álvaro de Luna. Véase sobre este aspecto el trabajo de TORrEs Fontes, J., "Los Condestables de Castilla en la Edad Media", Anuario de Historia del Derecho Español. Madrid 1971, págs. 89-98.

${ }^{9}$ En 1475 (4 de enero) doña Isabel le confirmó el cargo mandándole librar 40.800 maravedies anuales de ración y quitación, la misma cantidad que cobraba Iranzo. Véase A.G.S. Q. de C., legajo 37, tol. Pedro González de Mendoza. Están asentados los libramientos de 1475, 1476, 1477 y parte de 1478. Véase la obra de Martin Postigo, M. de la S. La Cancillería castellana de los Reyes Católicos, pág. 157.

yy Sobre la figura del cardenal Mendoza véanse los trabajos de Layna Seranano, F., Historia de Guadalajara y sus Mendozas en los siglos xv y xvi. Madrid 1942, t. II, págs. 40 y suc.; Merino Álvarez, A., El Cardenal Mendoza. Barcelona 1942 y Villalba, F. J. y Ruiz de Toledo, El Cardenal Mendoza (1428- 1495). Madrid 1988
} 
le condujo a obtener ya en 1442 el arcedianato de Guadalajara. Diez años después, a la edad de veinticuatro años fue presentado por su padre en la Corte de Juan II, donde, bajo la protección del arzobispo de Sevilla, don Alfonso de Fonseca, recibió muy pronto un puesto distinguido en la Capilla real ${ }^{99}$. Supo captarse la voluntad del monarca, quien, en 1454 , como maniobra politica para conseguir la amistad del eclesiástico, le propuso para ocupar el obispado de Calahorra-La Calzada, que estaba vacante por muerte de su titular ${ }^{100}$.

A la muerte de su padre en 1458 sus hermanos le reconocieron como jefe indiscutible de la familia y a partir de ese momento su influencia aumentó considerablemente. En octubre de 1467 alcanzó la codiciada mitra de Sigüenza ${ }^{101}$.

El 7 de marzo de 1473 obtuvo la dignidad cardenalicia y en este mismo año logró ser nombrado arzobispo de Sevilla y Canciller Mayor de la Poridad ${ }^{102}$. Ya hacia años que era miembro del Consejo Real.

Muerto Enrique IV, Mendoza abrazó la causa de Isabel la Católica convencido de la necesidad de proyectar la estabilidad y pacificación del reino mediante el apoyo incondicional a la autoridad monárquica. Los Reyes Católicos no fueron menos generosos con él de lo que habia sido Enrique IV y negociaron para él diversos títulos y prebendas. El último eslabón de su carrera eclesiática fue el arzobispado de Toledo, para el que fue designado por don Alonso Carrillo, a pesar de la rivalidad existente entre ambos, y del que tomó posesión el 19 de marzo de $1483^{103}$.

Este mismo año renunció el cargo de Canciller Mayor de la Poridad, que habia mantenido durante diez años por razones puramente prácticas y con muy poca vinculación a las funciones propias del puesto, en su hermano Pedro Hurtado de Mendoza, pues su nombramiento como arzobispo de Toledo le confería por sí mismo tal grado de preeminencia que la Cancillería perdia todo su valor ${ }^{104}$.

\footnotetext{
99 Layna Serrano, F., Ob. cit., pág. 41.

100 Ibidem, págs. 42-43; Villalba, F. J. y Ruiz de Toledo. Ob. cit., pág. 38.

101 Layna Serrano, F., Ob. cit., pág. 44; Villalba, F. J. y Ruiz de Toledo, Ob. cit., pág. 51 y suc. 60.

102 Layna Serrano, F., Ob. cit., pág. 44; Villalba, F. J. y Ruiz de Toledo, Ob. cit., pág. 59 y

${ }^{103}$ La iniciativa de la provisión del arzobispado partió de los Reyes Católicos. Véase VILlalba, F. J. y RuIZ dE TOLEdo, Ob. cit., págs. 184-185.

${ }^{104}$ La renuncia se produce el 4 de diciembre de 1483. A.G.S. Q. de C., legajo 32, fo! Hurtado de Mendoza, y la provisión real correspondiente tiene lugar el 18 del mismo mes, cit. por Villalba, F. J. y Ruiz de Toledo, Ob. cit., pág. 168. Publicado por Arribas Arranz., F., en Sellos de placa de las cancillerias regias castellanas, págs. 202 y 203 . Véase también R.A.H. Salazar, M-9, fol. 380v-381.
} 
Entre 1483 y 1489 el cargo de Canciller Mayor de la Poridad recayó en don Pedro Hurtado de Mendoza ${ }^{105}$, el último hijo varón del I Marqués de Santillana. Fue un hombre modesto entregado en cuerpo y alma a su hermano el cardenal, quien le acogió bajo su protección a la muerte de su padre el marqués en 1458, pues tanto éste como su hermano Juan eran muy jóvenes. Ambos figuran como donceles de Enrique IV desde enero de $1457^{106}$.

La influyente posición del obispo de Calahorra ya en aquellos años hizo posible la entrada de Hurtado de Mendoza en la Orden de Santiago, cuyo Maestre, don Rodrigo Manrique, le hizo trece de la Orden y Comendador de Usagre en 1476 , en recompensa a la ayuda prestada contra el arzobispo Carrillo ante los muros de Uclés ${ }^{107}$. En 1482, al ser designado su hermano el cardenal arzobispo de Toledo, le dio el Adelantamiento de Cazorla, perteneciente a la mitra toledana desde el siglo xIII, y le hizo Capitán de todas las tropas de la archidiócesis ${ }^{108}$. Desempeñó un papel muy activo en la guerra de Granada llevando consigo a sus sobrinos don Antonio de Mendoza, hijo del I Duque del Infantado y don Rodrigo de Mendoza, en el que habia renunciado el cargo de Canciller Mayor de la Poridad en $1489^{109}$.

En 1489 fue nombrado Canciller Mayor de la Poridad don Rodrigo de Mendoza ${ }^{110}$, hijo del cardenal don Pedro González de Mendoza y de doña Mencia de Meneses ${ }^{\prime \prime}$. Su trayectoria ha sido reconstruida tambièn por F. Layna Serrano, en especial en lo que respecta a sus numerosos es-

105 Provisión real haciendo merced del oficio de Canciller Mayor de la Poridad a Hurtado de Mendoza en A.G.S. Q. de C., legajo 32, fol. Hurtado de Mendoza. Publicado por Arribas ArRanz, F., Sellos de placa de las cancillerias regias castellanas, págs. 203-206.

${ }^{106}$ Recibian por dicho oficio 20 maravedies diarios de ración que les sumaban al año 7.200. A.G.S. Q. de C., leg. 3, fol. 592.

107 Layna Serrano, F., Ibidem, pág. 76.

${ }^{108}$ Itidem, pág. 77.

${ }^{109}$ Renuncia del ofico de Canciller Mayor de la Poridad hecha por don Hurtado de Mendoza en favor de su sobrino don Rodrigo en A.G.S. Q. de C., legajo 39, fol. Rodrigo de Niendoza, con fecha 7 de mayo de 1489. Publicado por Arribas Arranz en Sellos de placa de las cancillerias regias castellanas, págs. 208-210. Véase también R.A.H., Salazar, M-9, fol. $380 \mathrm{v}-381$.

110 Provisión real haciendo merced a don Rodrigo de Mendoza del cargo de Canciller Mayor de la Poridad en A.G.S. Q. de C., legajo 39, fol. Rodrigo de Mendoza, con fecha 11 de mayo de 1489, publicado por Arribas Arranz, F., en Sellos de placa de las cancillerias regias castellanas, págs. 212-213. Véase también R.A.H. Salazar, M-9, fol. $381 v-382$ v.

"El cardenal Mendoza tuvo dos hijos con doña Mencia de Meneses y uno con doña Ines de Tovar. Los tres fueron legitimados gracias a la benevolencia de los Reyes Católicos y del papa Inocencio VIII. Véase Layna Serrano, F., Ob. cit., págs. 242. 
La alta nobleza en la Cancilleria real castellana del siglo xv

cándalos amorosos, tanto en España como en Italia, donde el papa Alejandro Borgia trató de casarlo con su hija Lucrecia ${ }^{112}$.

\section{Los Notarios Mayores}

\subsection{Las notarias mayores de los reinos}

La configuración bajomedieval de las notarias mayores de los reinos se produjo durante el reinado de Alfonso $X$, quien, como es bien sabido, reorganizó la Cancilleria castellana adecuándola a las cada vez más complejas necesidades del momento.

Los notarios mayores eran en esta época los encargados de redactar los documentos a una orden del Canciller o del monarca, de vigilar que se escribieran por el escribano nombrado al efecto y con arreglo a las normas vigentes, de revisarlos y de que fueran registrados y sellados debidamente. El Espéculo dice que estos funcionarios estaban «...puestos sobre todos los escrivanos e an a mandar fazer los registros en que son las notas de todas las cartas... E demas an aguardar los seellos del rey" "'.3. Según Partidas unos eran nombrados por el Canciller y otros por el rey ${ }^{114}$ y podian ser clérigos o legos ${ }^{115}$.

La obra legislativa del rey Sabio no nos dice nada sobre el número de notarios que debia haber en la Cancillería y sobre su asignación a cada una de las circunscripciones en que estaba dividido el reino, pero sabemos que fue precisamente este monarca el creador de las notarias de León, Castilla y Andalucia ${ }^{116}$.

Durante el reinado de Sancho IV se conservó esta división, aunque el monarca reunió las tres notarias mayores en una sola persona desde 1290. Dicha concentración, sin embargo, no perduró en época de Fernan-

112 Ibidem, págs. 242-245.

${ }^{113}$ Espéculo, II, 12, 3, cit en Martin Postigo, La Cancilleria castellana de los Reyes Católicos, pág. 174 y en Torres Sanz, Ob. cit., pág. 99.

${ }^{114}$ Partidas $11,9,7$.

"1s Partidas 11, 11, 3. Desde finales del siglo XIII, sin embargo, ante las quejas de los procuradores que asistieron a las Cortes de Valladolid de 1295 , se estableció que los notarios mayores de los reinos fueran legos, ya que los clérigos, al acogerse al fuero eclesiástico, podian quedar impunes al ejercicio de la justicia: “Otrosí que los nuestros sellos que sean metidos en poder de dos notarios que sean legos..... Cortes..., 1, pág. 131. Estas protestas de los concejos se repitieron en reuniones de cortes posteriores

"SÁ Sanchez Belda, L., "La Cancillería castellana durante el reinado de Sancho iV...", pág. 179; Martin Postigo, M. de la S., La Cancillería castellana de los Reyes Católicos, pág. 174. 
do IV, que volvió al sistema de dividir por reinos las notarías y créo la Notaría Mayor del Reino de Toledo ${ }^{117}$.

Sobre los notarios recaía el peso efectivo de la Cancilleria, pues ellos eran los que verdaderamente supervisaban todo el proceso de redacción del documento real hasta su revisión, lo que requería que fueran personas cualificadas y con una dedicación directa. Cada uno llevaba los asuntos referidos al reino del que era titular, aunque a veces esta division no se respetó, y unos y otros despacharon documentos de fuera de sus reinos ${ }^{118}$. Con frecuencia intervinieron tambièn en la administración de las rentas de la Corona y en multitud de comisiones regias de toda indole como consecuencia del grado de influencia personal del que disfrutaron junto al monarca ${ }^{119}$. Dada la importancia de las personas que desempeñaron este oficio y la variedad de misiones que realizaban fue necesario, en muchos casos, nombrar sustitutos que ejercieran por ellos los cargos. Cada Notario tenía tres escribanos a su cargo: uno de cámara, otro de libro y otro de registro.

Los distintos monarcas legislaron sobre las cualidades y las funciones que debian corresponder a los notarios mayores a través de los sucesivos Ordenamientos de Cortes. Alfonso XI y Enrique II se preocuparon de que las notarias recayeran en «omes buenos, e honrados e sabidores que pudieran servir dichos oficios y no los arrendasen " ${ }^{120}$. Y dichas disposiciones se repitieron en reuniones posteriores: Cortes de Burgos de 1379 , Cortes de Briviesca de 1387, Cortes de Palenzuela de 1425, etc. Esto demuestra que las notarias mayores suponian una importante fuente de ingresos para los que las tenian al arrendarlas, lo que hacia que el cargo no fuera atendido por personas debidamente cualificadas ${ }^{121}$.

A fines del siglo xv, a raiz de la conquista de Granada, se créo la Notaria Mayor del Reino de Granada. En esta época los notarios mayores aparecen equiparados con los otros dos altos cargos de la Cancilleria -Mayordomo y Canciller - respecto a los derechos que cobraban por la expedición de los documentos que hubieran de librar ${ }^{122}$.

"Sanchez Belda, L., "La Cancilleria castellana durante el reinado de Sancho IV...", pág. 180.

${ }^{118}$ Ibidem, pág. 182

119 Ibidem, págs. 182-183.

${ }^{120}$ Cortes de Toro de 1369. Cortes..., II, pág. 168, cit. en Martin Postigo, M. de la S., La Cancilleria castellana de los Reyes Católicos, págs. 175-176.

121 Martin Postigo, M. de la S., La Cancilleria castellana de los Reyes Católicos, pág. 177.

122 Cortes de Madrigal de 1476. Cortes..., t. IV, pág. 26, cit. por Ibidem, pág. 178. 


\section{LOS NOTARIOS MAYORES DE LEON}

A comienzos del siglo xv encontramos como Notario Mayor del Reino de León a Pedro Manrique, uno de los personajes más relevantes de la vida política castellana durante casi toda la primera mitad de la mencionada centuria. Este noble influyó tan poderosamente en los bandos y disturbios nobiliarios que llenaron el reinado de Juan II, que Fernán Pérez de Guzmán diria en sus Generaciones y Semblanzas: "no fue alguno en el que él no fuese, no por deservir al Rey, ni procurar daño al Reyno, mas por valer y aver poder, de to cual muchas veces se siguen escándalos y males" :23.

Pedro fue hijo del Adelantado de Castilla, Diego Gómez Manrique y de Juana de Mendoza. Muerto su padre en la batalla de Aljubarrota, le sucedió con tan sólo cuatro años en sus bienes y señorios bajo la tutoria de su madre, así como en el Adelantamiento, oficio del que Juan I le hizo merced, aunque como era menor de edad, el monarca quiso que ejerciese dicho cargo su pariente Gómez Manrique ${ }^{124}$.

Al parecer, en 1405, Pedro Manrique recibió los oficios de Adelantado Mayor del León y Notario Mayor del Reino de León. Según Salazar y Castro al fallecer el Almirante Diego Hurtado de Mendoza, señor de Hita y Buitrago, tío de Pedro Manrique, decidió el rey que le sucediese en el Almirantazgo su cuñado Alonso Enríquez, entonces Adelantado del Reino de León. Al quedar vacante el Adelantamiento el monarca entregó dicho oficio a Pedro, junto con la Notaria, por «complacer -dice el mencionado autor- a su padrastro el Almirante Alonso Enriquez», o "quizá por apartarle del derecho que tenía al Adelantamiento de Castilla", cargo que como hemos dicho tenía su primo Gómez Manrique y que el rey creyó conveniente que siguiera ejerciendo ${ }^{125}$.

A partir de entonces inició una agitada trayectoria política que tan díficil resulta reconstruir en breves lineas. Durante la minoria de edad de Juan II fue miembro del Consejo de Regencia y uno de los nobles que este monarca eligió por Consejero al proclamarse su mayoria de edad. Por su vinculación personal y política con Enrique, uno de los Infantes de Aragón, participó en el "secuestro" del rey en Tordesillas y en el asedio

123 Pérez de Guzmán, F., Generaciones y Semblanzas, pág. 84.

124 Nombramiento del 15 de septiembre de 1385 en Valladolid. R.A.H. Salázar, M-1, fol. 98r. Publicado por Salazar y Castro, L., en Pruebas, pág. 54 y por Perez Bustamente, E., en El gobierno y la Administración de los Reinos de la Corona de Castilla (1230-1474), pág. 187.

125 SALAzAR y CASTro, Luis, Casa de Lara, t. ll, pág. 13; MITRE FERNÁNDEZ, E., Evolución de la nobleza en Castilla bajo Enrique III (1396-1406). Valladolid 1968, pág. 190. Ninguno de estos dos autores indica de dónde han obtenido esta información. 
del Castillo de Montalbán ${ }^{126}$. Apresado Don Enrique en 1422, el Adelantado se vió obligado a huir a Aragón ${ }^{127}$, aunque fue perdonado en $1425^{128}$, y a su regreso a Castilla fue uno de los nobles que favoreció el destierro del privado regio, don Álvaro de Luna.

No obstante, en 1429 dio un giro a su actuación política y combatió con el Condestable en Navarra y Extremadura a los Infantes de Aragón, cuyos bienes serian confiscados y repartidos. De ellos recibiria como merced por sus servicios la villa de Paredes de Nava en $1429^{129}$. Dos años después, su carrera politica alcanzaba el cenit, al nombrarle Juan II gobernador del reino mientras él estuviese ausente en la guerra de Granada ${ }^{130}$. Tras unos años en la gracia real fue apresado en 1437, sin que se conozcan aún cuáles fueron los motivos que indujeron al monarca a tomar esta medida, que resultó muy impolitica ${ }^{13 !}$. Desde ese momento y hasta su muerte mantuvo su apoyo a los Infantes de Aragón y su enfrentamiento con don Áivaro de Luna ${ }^{132}$.

El Adelantado falleció el 21 de septiembre de 1440 en Valladolid ${ }^{133}$. En su testamento dado el día anterior, además de fundar diversos mayorazgos, dejaba a su primogénito Diego Manrique los oficios de Adelantado Mayor de Léon y Notario Mayor del Reino de León ${ }^{134}$, manda testamentaria que aprobaria el monarca ${ }^{135}$.

Diego Manrique, I Conde de Treviño, habia nacido hacia 1409 y aunque habia participado en algunos acontecimientos políticos y cortesanos, tales

${ }^{126}$ Crónica de Don Álvaro de Luna, ed de Juan de Mata Carriazo. Madrid 1940, pág. 36. Halconero, pág. 5 y Refundición, pág. 41; Diez DE Games, Gutierre, El Victorial. Crónica de don Pero Niño. Madrid 1989, págs. 285-287.

"Crónica de don Alvaro de Luna, pág. 36.

${ }^{22}$ Halconero, pág. 11 y Refundición, pág. 49. Un año después volvia a perder el favor regio, ya que el monarca ordenaba por su cédula dada en Valladolid el 6 de septiembre de 1426 que se le secuestrasen todos sus bienes y oficios. A.H.N. Osuna, Carpeta 56, n. 15. Publicado por Pérez Bustamante, R., Ob. cit., pág. 209.

${ }^{129}$ Halconero, pàg. 52 y Refundición. pàg. 89. La villa se la concedió el rey por su albalá dado en Medina del Campo el 8 de diciembre de 1429, pero el privilegio le fue dado en Valladolid, el 3 de julio de 1430. Salazar y Castro, L., Pruebas, págs. 246-250.

130 Salazar y Castro, L., Pruebas, págs. 250-251. Nombramiento dado en Medina del Campo el 12 de marzo de 1431. Este documento también puede consultarse en PÉrEz BUSTAMANTE, R., ob. cit, págs. 215-218.

131 Halconero, págs. 249-251; y Refundición, págs. 216-217.

$13:$ SuÁREZ FERnÁNDEZ, L., expone magistralmente la cadena de complicados acontecimientos politicos de estos años en su obra Nobleza y monarquia. Puntos de vista sobre la historia politica castellana del siglo xv. 2. edición. Valladolid 1975, págs. 147-151.

${ }_{133}$ Halconero, pág. 347

${ }^{134}$ R.A.H. Salazar, M-2, fols. 83 a 93. Publicado por SALAzAR y CASTRO, L., en Pruebas, págs. 256 a 261.

${ }_{133}$ Halconero, pág. 347 
como justas y fiestas, ${ }^{136}$ fue a partir de la muerte de su padre cuando pasó a gozar de cierta relevancia en la vida política del reino, pero sin llegar a tener un papel tan destacado cono aquél.

Siguiendo los pasos de su progenitor, Diego Manrique se adhirió a la liga nobiliaria que consiguió el que seria segundo destierro de don Álvaro de Luna. No participó, sin embargo, en la batalla de Olmedo (1445), aunque refugió en sus tierras a algunos de los participantes vencidos, como el Almirante, el Conde de Benavente y el señor de Berlanga ${ }^{137}$. En 1448 desde su villa de Navarrete ayudó a huir a Navarra al Almirante y a Pedro Quiñones, a los que el rey habia mandado detener junto a otros para evitar nuevas confederaciones de nobles que trataban de introducir a los reyes de Aragón y de Navarra en Castilla. Esta conducta costó al Adelantado la entrega de la mencionada fortaleza de Navarrete y la de Treviño por mandato regio ${ }^{138}$. En los años siguientes Diego mantuvo su adhesión a las ligas nobiliarias que favorecieron la prisión y muerte de don Álvaro de Luna.

En 1453 aproximadamente, el monarca le concedió el titulo de Conde de Treviño ${ }^{139}$, aunque debió permanecer poco tiempo en la gracia real, pues al final del reinado de Juan II estaba preso en Segovia por orden del rey, sin que de momento se conozcan los motivos. Nada más acceder al trono, Enrique IV mandó liberarle y restituirle todos sus bienes ${ }^{140}$, y al comienzo del reinado permaneció, como el resto de los miembros del linaje Manrique en el servicio del rey, participando en las campañas granadinas de esos años ${ }^{141}$.

En 1458 falleció Diego Manrique en su villa de Amusco. Por su testamento, redactado el 13 de octubre de ese año ${ }^{142}$, dejaba a su primogénito Pedro Manrique, sus principales bienes, asi como el cargo de Adelantado Mayor de León. Sin embargo, con el deseo de que su segundo hijo y homónimo quedase también dignamente dotado, además de las tenencias de Davalillo y Vellivio, y de 20 lanzas de las 58 que tenia del rey, le dejó

${ }^{36}$ Halconero, pág. 157. Refundición, págs. 152-153

${ }^{13 i}$ Perez de Guzman. F., Crónica de Juan II, año 1445, cap. 81 y 82, págs. 629 y 634.

${ }^{138}$ Crónica de don Álvaro de Luna, págs. 213-214. Crónica de Juan II, año 48, cap. 105106. págs. $657-658$.

39 LOPEZ de HARO. Alonso, Nobiliario Genealógico de los Reyes y Titulos de España vol. 1. Madrid 1622, fol. 304

140 Valera, Diego de, ob. cit., pág. 7, y Enriouez del Castillo, Diego, ob. cit., pág. 102. También debió devolverle el oficio de Notario pues en 1455 cobraba los derechos correspondientes a dicho cargo. A.G.S. Diversos de Castilla, legajo 4, n." 76.

141 Valera, Diego de, ob. cit., pàg. 11. Enriquez del Castillo, Diego, ob. cit., pág. 106.

142 Salazar y Castro, L., Pruebas, págs. 272-276. 
el oficio de Notario Mayor del Reino de León. Esta claúsula testamentaria produjo desaveniencias entre ambos hermanos, y Pedro Manrique se resistió a cumplirla, obteniendo incluso el refrendo de Enrique IV, que en 1461 por un albalá, le hacia merced de todos los oficios y dignidades que habia tenido su padre, incluida la Notaria ${ }^{143}$. Parece, sin embargo, que Pedro Manrique cedió finalmente el cargo a su hermano, porque en una claúsula de su testamento en la que dejaba ciertos legados a sus sobrinos Alonso y Pedro Manrique dice «que se partan del desvario en que se pusieron en decir que era yo obligado en algo a su padre, antes lo era el a mi, por le aver yo dado la Notaria de León, aviendomela dado a mi el Rey don Enrique» ${ }^{144}$.

No sabemos durante cuánto tiempo tuvo Diego Manrique el cargo de Notario Mayor del Reino de León, porque carecemos de noticias tanto sobre el oficio en estos años, como sobre este personaje.

Según M. de la S. Martín Postigo, en su trabajo monográfico dedicado a la Cancilleria de los Reyes Católicos, a comienzos de este reinado tenia dicha Notaría Francisco de León ${ }^{145}$, lo que indica que la familia Manrique perdió su vinculación con el oficio, sin que conozcamos por el momento cuáles fueron los motivos.

\section{LOS NOTARIOS MAYORES DE TOLEDO}

Este oficio estuvo vinculado a lo largo del siglo xv a los Silva, linaje de origen portugués. A comienzos de la centuria gozaba la Notaria Alfonso Tenorio de Silva ${ }^{146}$, quien en 1425 la renunció en su hijo Juan de Silva, I conde de Cifuentes. Este personaje, nacido hacia 1399, inició su trayec-

143 R.A.H. Salázar, M-8, fols. 143v y 144. Publicado por Salazar y Castro, L., Pruebas, pág. 220 y por Pérez Bustamente, R., Ob. cit., pág. 246.

144 R.A.H. Salazar, M-1, fols. 92 a 96. Publ. por Salazar y Castro, L., Pruebas, págs. 299304.

145 Martin Postigo, M. ${ }^{a}$ de la S., La Cancillería castellana de los Reyes Católicos, pág. 178. Esta autora opina que Francisco de León debió tener el oficio durante todo el reinado, porque los Reyes hicieron merced de la notaria, por su carta dada en Madrid, el 10 de enero de 1503 a su hermano Lope de León, según consta en A.G.S. Q. de C., legajo 31, fol. Lope de León. Puede que estos personajes estuviesen emparentados con otro Lope de León que aparece curiosamente como Notario Mayor de León en junio de 1454, quizá mientras Diego Manrique, conde de Treviño, permaneció fuera de la gracia real. A.G.S. Q. de C., legajo 31 , fol. 563 .

${ }^{146}$ Alfonso Tenorio era Señor de Vililla y de Barcience, así como alcalde mayor de Toledo desde los quince años. Fueron sus padres Arias Gómez de Silva uno de los nobles portugueses que se instalaron en Castilla a fines del xiv- y Doña Urraca Tenorio. SALAZAR y CAstro, L., Historia Genealógica de la Casa de Silva (en adelante Casa de Silva), t. I. Madrid 1685, pág. 187. 
toria politica como doncel de Juan II. Siguiendo los pasos de su padre mantuvo una fiel relación con el Condestable don Álvaro de Luna, amistad que le valdria a su progenitor la concesión de la villa de Barcience en 1427, y a él un ventajoso matrimonio con Leonor de Acuña, prima del Condestable. Desde 1425 gozó por renuncia de su padre de la dignidad de Notario Mayor de Toledo ${ }^{147}$, y en 1428 Juan II le hacia merced de las Escribanias de diezmos, aduanas y cosas vedadas de los puertos de los obispados de Calahorra y Sigüenza ${ }^{148}$.

Fieles a su politica de apoyo a don Álvaro de Luna, colaboraron con él en las campañas que mantuvo con sus enemigos los infantes de Aragón y otros sectores de la nobleza en Extremadura, donde tomaron en 1430 el castillo de Trujillo ${ }^{149}$. En este mismo año, y en premio a sus servicios, el monarca concedió a Juan de Silva la villa de Cifuentes - merced que le seria confirmada nuevamente en 1436- tras el despojo de bienes que sufrieron los infantes de Aragón ${ }^{150}$. Acompañó al Condestable por tierras granadinas en la campaña de $1431^{151}$, y en 1434 Juan II le envió como embajador al Concilio de Basilea ${ }^{152}$. Ese año recibió el cargo de Alférez Mayor del Rey ${ }^{153}$, y la merced de las "penas de las tahurerías" de la ciudad de Sevilla, su tierra y su término, que tenia Ruy Diaz de Mendoza ${ }^{154}$, todo ello gracias a la «protección» de don Álvaro de Luna, a quien, como prueba de su lealtad, acompañó al destierro en $1439^{155}$. En los años siguientes, reincorporado a la Corte con el Condestable, tuvo el puesto de Mayordomo Mayor de la reina doña Maria ${ }^{156}$, participó en el bando real en la batalla de Olmedo de 1445, donde como Alférez portaba el estandarte regio, y fue nombrado guarda del rey en $1451^{157}$.

Tras un periodo de tiempo retirado en sus tierras, volvió a la vida política, encontrándose entre los asistentes a la proclamación de Enrique IV como rey ${ }^{158}$, quien por su fidelidad le recompesaría con el título de Conde de Cifuentes en $1455^{159}$, aunque pronto abandonaría la Corte regresando

${ }_{147}$ A.G.S. Q. de C., legajo 3, fol. 680, según Gómez Izquierdo, A., Ob. cit., pág. 79.

${ }^{148}$ Salazar y Castro, L., Casa de Silva, t. I, pág. 221.

149 Pérez de Guzman, F., Crónica de Juan II, pág. 471.

${ }^{150}$ Suarez Fernandez, L., Nobleza y monarquia, pág. 103.

${ }^{151}$ Halconero, pág. 93 y Refundición, pág. 116.

152 Refundición, pág. 150.

${ }^{153}$ Tenia de quitación con dicho cargo 20.000 maravedies, por muerte de Gutierre Delgadillo. A.G.S., Q. de C., legajo 3, fol. 680. Gómez Izoulerdo, A., Ob. cit., pág. 81.

${ }_{154}$ A.G.S. M. y P., legajo 12, fol. 64, cit. por Gomez Izouleruo, A., Ob. cit., pảg. 81

15j Perrez de Guzman, F., Crónica de Juan II, pág. 557.

${ }^{156}$ Salazar y Castro, L., Casa de Silva, t. I, pág. 237.

ist A.G.S. Q. de C., legajo 3, fol. 681, cit. por Gomez izouierdo, A., Ob. cit., pág. 84.

158 Palencia, Alonso oe, Ob. cit., pág. 60.

1.99 Salazar y Castro, L., Casa de Silva, t. I, pág. 242. 
a sus señorios, donde permaneció hasta su muerte, que tuvo lugar el 27 de septiembre de $1464^{160}$.

En 1458 Juan de Silva habia fundado tres mayorazgos en virtud de la facultad que para ello le había dado Juan II en 1449: uno con la villa de Barcience, y otro con la de Cifuentes, su castillo, término, aldeas, y lugares de Vililla y Torrecilla, ambos para su primogénito Alonso de Silva. El tercer mayorazgo que incluia la villa de Montemayor, castillo y aldeas, lo estableció para Juan de Ribera, hijo habido en su segunda mujer Inés de Ribera ${ }^{161}$, quien le sucederia en el cargo de Notario Mayor.

La trayectoria politica de Juan de Ribera, señor de Montemayor, corre paralela a la de su hermano Alonso de Silva, II Conde de Cifuentes, y a la de su sobrino Juan, del que E. Benito Ruano dice era su consejero ${ }^{162}$. Con ellos siguió la parcialidad del Infante Alfonso, por quien alzaron Toledo, y participó en los desórdenes de 1467 entre conversos y cristianos viejos en dicha ciudad, apoyando a los primeros ${ }^{163}$. En 1474 Juan de Ribera y su sobrino abrazaron la causa de los Reyes Católicos ${ }^{164}$. Al año siguiente, a su entrada en Toledo, Isabel aprobaba que Juan de Ribera tuviese el Alguacilazgo Mayor de dicha ciudad — de la que también era regidor-, mientras el titular del oficio - el nieto de Pedro López de Ayala- fuese menor de edad ${ }^{165}$. Asimismo, en 1475 los monarcas le confirmaban el cargo de Notario Mayor del Reino de Toledo ${ }^{166}$.

En 1480 los reyes le concedieron el oficio de Capitán General de la Frontera de Navarra ${ }^{167}$, cargo en el que les prestó grandes servicios, lo mismo que como su embajador en Francia ${ }^{168}$. Los monarcas le nombraron además Corregidor de Guipúzcoa en 1489 y de las ciudades de Lo-

${ }^{160}$ Ibidem, pág. 243.

${ }^{16 .}$ lbidem, págs. 248-253.

162 Benito Ruano, E., Toledo en el siglo xv. Vida política. Madrid 1961, pág. 115.

${ }^{163}$ Sobre este particular véase lbidem, págs. 89-102.

164 Ibidem, pág. 121.

${ }^{105}$ En virtud de un acuerdo matrimonial entre Pedro López de Ayala y Don Juan de Ribera para casar al nieto del primero con la hija del segundo, habian establecido que la tenenecia del oficio de Alguacil Mayor recayese en Don Juan, hasta que el mencionado nieto del conde tuviese edad para su ejercicio. La Reina aprobó este capitulo en Toledo, el 27 de mayo de 1475. A.G.S. R.G.S, fol. 458. Publicado por Benito Ruano, E., Ob. cit., págs. 290-291.

${ }_{166}$ R.A.H. Salazar, M-36, fol. 169, 1475, marzo, 3.

167 Salazar y Castro, L., Casa de Silva, t. I, pág. 439.

168 Zurita, Jerónimo, Anales de la Corona de Aragón. Zaragoza 1977, lib. 20, cap. 53, pág. 454. 
groño, Calahorra, y Alfaro en $1492{ }^{169}$. A la muerte de Isabel la Católica, permaneció fiel a Fernando, frente al amplio sector de la nobleza que se decantó por el nuevo monarca Felipe el Hermoso, a pesar de los requerimientos del Duque de Nájera para que se adhiriese a dicha causa. Por este motivo a su llegada a Castilla, Felipe le cesó en el cargo de Capitán General de la Frontera, oficio que le seria devuelto por Fernando a su regreso al reino castellano, además de otras mercedes diversas por sus leales servicios ${ }^{170}$.

Juan de Ribera falleció en 1515. Le sucedió en sus señorios su hijo Juan de Silva y Ribera, II Señor de Montemayor, quien tuvo el oficio de Notario Mayor de Toledo desde 1491, por renuncia de su padre ${ }^{171}$. De su trayectoria politica cabe resaltar su colaboración en la guerra de Navarra, y su nombramiento de Capitán de las guardas de hombres de armas. También destacó por su participación en las Comunidades y por su papel como asistente en la ciudad de Sevilla ${ }^{172}$. En 1538 Carlos V le nombró Marqués de Montemayor recompensando sus leales servicios a la Corona ${ }^{173}$.

\section{LOS NOTARIOS MAYORES DE CASTILLA}

Del primer noble de quien tenemos noticia como Notario Mayor de Castilla, es de don Álvaro de Luna, el célebre Condestable. Seria imposible reconstruir pormenorizadamente la trayectoria politica de este personaje, porque ello nos obligaria a narrar la historia de Castilla durante el reinado de Juan 11 , lo que, además de no ser el objeto de este estudio, supondría una larga exposición innecesaria al existir gran número de trabajos sobre esta excepcional figura política ${ }^{174}$. Como es bien sabido, don

${ }^{169}$ Fue corregidor de Guipuzcua entre 1489 y 1494. A.G.S. R.G.S. 9 de febrero de 1490 fol. 108; 26 de octubre de 1493, fol. 47; Entre 1492 y 1494 fue corregidor de Logroño. 16 de abril de 1492, fol. 204, cit. por LUNENfELo, Marvin, Los corregidores de Isabel la Católica. Barcelona 1989, págs. 214 y 216, por lo que se deduce que o bien alternó dichos oficios o los tuvo simultáneamente

170 Salazar y Castro, L., Casa de Silva, t. I, pág. 452.

${ }^{17}$ Juan de Ribera renunció el oficio el 15 de enero de 1491, en Sevilla. El rey concedió el cargo a su hijo Juan de Silva el 13 de abril de 1491. A.G.S. Q. de C., legajo 29, fol. 795. Publ. por MARTn Postigo, M. ${ }^{a}$ de la S., La Cancilleria castellana de los Reyes Católicos, págs. 296-297.

1: Un semblante biográfico pormenorizado del personaje en SALAZAR Y CASTRO, L., Casa de Silva, t. I, págs. 462-472.

$1 / 3$ Ibidem, pág. 471.

174 Rizzo y Ramirez, J., Juicio crítico y significación política de don Álvaro de Luna. Madrid 1865. Silıo, C., Don Álvaro de Luna y su tiempo. Madrid 1941; Suárez Fernandez, L., Nobleza y Monarquía, págs. 119 a 179; PÉREZ dE GuzMÁN, F., Generaciones y Semblanzas: Round, N., The greatest man uncrowned. A study of the fall of don Alvaro de Luna. London 1986 y la ya citada Crónica de don Álvaro de Luna. 
Álvaro, que nació hacia 1390, fue hijo bastardo de don Álvaro de Luna, señor de Cañete, Copero Mayor de Enrique III, y de una mujer llamada María Fernández de Jaraba. Fue educado por su tio Juan Martinez de Luna, alférez del Infante don Fernando ${ }^{175}$. En 1408 gracias a la protección de otro tío, don Pedro de Luna, arzobispo de Toledo, se introdujo en la Corte como doncel del rey Juan II, monarca del que pronto se ganaria su confianza, convirtiéndose en su privado. Desde ese momento don Álvaro, para fortalecer la soberania regia, dedicó todos sus esfuerzos a luchar contra los poderosos Infantes de Aragón y la levantisca nobleza que ansiaba conseguir el poder político, por lo que se le ha considerado un defensor de la institución monárquica. Sin embargo, tambièn se ha dicho que combatió por imponer un gobierno personal que confundia con la autoridad del rey ${ }^{176}$, motivo por el cual en ocasiones se ha hablado de la "tirania" del Condestable ${ }^{177}$.

La tenaz oposición nobiliaria, fortalecida con el apoyo del principe heredero, y la perdida del favor real, provocaron finalmente su caida. Tras una serie de oscuros sucesos, el rey dictó auto de prisión contra su privado, que fue juzgado con premura y ajusticiado en Valladolid el 2 de julio de 1453.

Durante su trayectoria politica logró reunir un rico patrimonio y cuantiosas mercedes ${ }^{178}$. De todo ello lo que más nos interesa destacar es su acumulación de cargos: Condestable desde $1423^{179}$, Camarero de la Cámara de los Paños tambièn desde ese mismo año ${ }^{180}$, Consejero, Notario mayor del Reino de Castilla, oficio en el que le hemos encontrado por primera vez en $1431^{181}$, y sin olvidar claro está su nombramiento como Maestre de Santiago en 1445. No obstante, el 31 de agosto de 1445 , Juan II hacia merced de los oficios de Notario Mayor de Castilla y de

1is SILIO, C., Ob. cit., pág. 23.

1/6 Suarez Fernandez, L., Nobleza y Monarquia, pág. 148

16idem, pág. 165.

1/8 Un visión bastante pormenorizada de algunas rentas de don Álvaro, a partir de los datos obtenidos en la sección de Mercedes y Privilegios del Archivo General de Simancas, nos la ofrece Gomez Izoviero, A., en Ob. cit,, págs. 19-22; también puede consultarse los datos que aporta SuARez FERnANDEZ, L., en "Un Libro de Asientos de Juan ll", págs. 328-329 y Franco Silva, A. en «El destino del patrimonio de don Álvaro de Luna, Problemas y conflictos en la Castilla del siglo Xv", Anuario de Estudios Medievales, n. 12 , 1982, págs. 549 . 583.

${ }^{175}$ Nombramiento por carta dada en Valladolid, el 10 de septiembre de 1423 , contirmada por privilegio rodado en Madrid, a 27 de enero de 1424. TORRES FonTES, J., «Los Condestables de Castilla en la Edad Media», págs. 77-78. Tenia de quitación con el oficio 40.000 maravedies cada año. A.G.S. Q. de C., legajo 1, fol. 1. Gomez IzQuierdo, A., Ob. cit, pág. 20.

${ }^{180}$ A.G.S. Q. de C., legajo 1, fol. 1. Gómez IzQuierdo, A., Ob. cit., pág. 20.

181 A.G.S. Diversos de Castilla, legajo $4, n .{ }^{\circ} 77$. 
Condestable, a su hijo Juan de Luna, probablemente para que los ejerciera a la muerte de su padre, ya que don Álvaro siguió teniendo ambos cargos ${ }^{182}$.

A la muerte de don Álvaro de Luna, aparece como Notario Mayor de Castilla, Gonzalo de Alba, que cobraba trece mil maravedies de quitación ${ }^{183}$ por dicho oficio. Resulta extraña la presencia de este personaje en el cargo, pues no pertenece a la nobleza. La falta de referencias documentales nos impide conocer qué razones luvo el rey para su nombramiento. Cabe preguntarse si este personaje habria sido antes lugarteniente en el oficio y pasó a ocuparlo mientras el monarca hacia una nueva provisión.

Desde 1455 sabemos que gozó la Notaria Mayor de Castilla Pedro Girón. Este célebre personaje que nació hacia 1423, entró a servir en la Corte como paje, y al principio tanto él como su hermano, el no menos famoso Juan Pacheco, futuro Marqués de Villena, fueron favorecidos por don Álvaro de Luna. Aunque Juan II le hizo diversas mercedes, fue Enrique IV, primero como príncipe y luego como rey, quien más le agració y contribuyó a su gran ascenso politico ${ }^{184}$. En 1445 Pedro Girón fue elegido Maestre de Calatrava ${ }^{185}$, cargo que junto a su rico patrimonio le convirtió en uno de los personajes de mayor iniluencia politica del reino.

18. SuARez Fernández, L., "Un libro de asientos de Juan ll». Don Álvaro de Luna aparece cobrando derechos por los cargos de Condestable. Camarero Mayor de la Cámara de los Paños, y por Notario Mayor de Castilla en 1447, fecha aproximada que este autor ha dado a dicho !ibro, pág. 329. No obstante, en cierta noticia de una cédula de Juan ll dada el 31 de agosto de 1445 , el monarca ordena a sus contadores mayores que asienten en los libros de la contaduria 40.000 maravedies de quitación al nuevo Condestable de Castilla, su ahijado Juan de luna, por renuncia que de este oficio le ha hecho su padre don Álvaro de Luna. R.A.H. Salazar. M-5, fol. $280 \mathrm{v}$. En esta misma signatura aparece también otra noticia de una cédula dada el 3 de agosto de 1445, por la que Juan II aprueba la sucesión de Juan de Luna, en los empleos y honores de Condestable de Castilla, Conde de San Esteban de Gormaz, Notario Mayor de Castilla y Camarero Mayor de la Cámara de los Paños por renuncia de su padre don Álvaro de Luna. Asimismo, en R.A.H. Salazar, M-9 fol. $57 v$, se encuentra un extracto de la cédula de Juan II por la que hace merced del oficio de Notario mayor de Castilla a Juan de Luna hijo de don Ảlvaro de Luna. 1445, agosto, 31. sin lugar.

${ }_{183}$ A.G.S. Q. de C., legajo 1, fol. 137 y legajo 3, fol. 334, citado por Gomez IzQuiERdo, A., Ob. cit., pág. 74 .

184 Todas sus mercedes, asi como su trayectoria pclítica puede verse en los siguientes trabajos: O'CALLAGHAM, J., "Don Pedro Girón, master of the Order of Calatrava (1445-1466)» Hispania, vol. LXXXIII. Madrid 1961; UhaGon, F., Ordenes Militares. Discurso leido ante la Real Academia de la Historia. Madrid 1898; Solano Ruız, E., La Orden de Calatrava en el siglo xv. Los Señorios castellanos de la Orden al fin de la Edad media. Sevilla. 1978: y Aguado GonzÁlez, J., El ascenso de un linaje castellano en la segunda mitad del siglo xv: los Téllez Girón, Condes de Urueña. El origen del señorio de Osuna. 2 vols. Tesis doctoral Univ. Complutense. Madrid 1991.

18: Al parecer el nombramiento tuvo lugar el 19 de septiembre de 1445. O'CALLAGHAN, J. «Don Pedro Girón...», pág. 354. 
En 1453 se adhirió, con tropas de la Orden, a la gran liga nobiliaria que se formó contra el Condestable don Álvaro de Luna, y consiguió su caida y ejecución. Pudo ser entonces cuando Juan II le hizo merced de los oficios de Camarero Mayor de la Cámara de los Paños y de Notario Mayor de Castilla, cargos que habia tenido el Condestable, pero no hay noticias seguras. En lo que a la Notaria se refiere, ya hemos señalado que la primera mención en dicho oficio es del año $1455^{186}$.

En los primeros años del reinado de Enrique IV colaboró activamente en las campañas granadinas ${ }^{187}$, así como en el gobierno, con su ya citado influyente hermano, el Marqués de Villena. En 1461 luchó en la frontera de Navarra para rescatar varias plazas de las que se habia apoderado Juan II de Navarra, y conquistó, entre otras, la de Viana, que defendía mosén Pierres de Peralta ${ }^{188}$. Reanudada la guerra de Granada en 1462 , Pedro Girón con las tropas de la Orden tomó la posición estratégica de Archidona ${ }^{189}$.

Relegados él y su hermano del gobierno por el rey, se sumaron a la liga de nobles que destronó a Enrique IV y proclamó al Infante Alfonso como rey. Durante 1465 Pedro Girón permaneció en Andalucia para someter los núcleos que eran fieles al legítimo monarca, y mantuvo importantes enfrentamientos con Miguel Lucas de Iranzo que defendia Jaén ${ }^{190}$.

En febrero de 1466 el Maestre y su hermano, Juan Pacheco propusieron a Enrique IV un acuerdo por el que el Marqués se comprometia a volver al servicio del rey, y entregarle al Infante Alfonso para su custodia; por su parte, Girón le aseguraba la lealtad de la Orden de Calatrava y del área andaluza fiel a Alfonso. A cambio de todo ello el monarca debia romper los compromisos matrimoniales con Portugal, y casar a la Infanta Isabel con el Maestre. Aunque el rey aceptó, Pedro no pudo ver cumplido su deseo pues cuando se dirigía a celebrar el enlace, enfermó en Villarrubia de los Ojos, Ciudad Real, y murió poco después, el 4 de mayo de 1466, con 43 años de edad. Como miembro de la Orden de Calatrava Pedro Girón no contrajo matrimonio, pero convivió y tuvo descendencia con Isabel de ias Casas.

196 A.G.S. Diversos de Castilla, legajo 4, n. 76, cit por Aguado Gonzalez, J., en Ob. cit., págs. 993-994.

187 Solano, E., Ob. cit, págs. 95-97.

188 Ibidem, pág. 97.

199 Ibidem, pág. 101

190 Ibidem, pág. 382. 
Le sucedió Alfonso Téllez Girón, I Conde de Urueña ${ }^{191}$, uno de los hijos bastardos que el Maestre de Calatrava, habia tenido con la mencionada Isabel de las Casas. Alfonso nació en 1453 en el Moral de Calatrava ${ }^{192}$, y en 1459 fue legitimado por el papa Pio II, junto con sus hermanos, Juan y Rodrigo ${ }^{193}$. Poco podemos decir de este personaje, salvo que fue designado heredero por su padre en sus principales bienes y oficios, entre los que se encontraba el de Notario Mayor de Castilla, según consta en su testamento ${ }^{194}$. Su tío el Marqués de Villena se encargó de su tutela. Alonso murió prematuramente en $1469{ }^{195}$, por lo que su corta edad impide cualquier reconstrucción de trayectoria politica.

A la muerte de Alonso, cumpliéndose su voluntad ${ }^{196}$, heredó el patrimonio Juan Téllez Girón, II Conde Urueña, el tercer hijo de Pedro Girón, porque Rodrigo, su segundogénito, pertenecia a la Orden de Calatrava, de la que era Maestre ${ }^{197}$. Como Juan era menor de edad administró su patrimonio, el Marqués de Villena, su tío. En 1469, año del fallecimiento de Alonso Téllez, el rey hacia merced del oficio de Camarero Mayor de la Cámara de los Paños con 15.000 maravedies de quitación ${ }^{198}$, y de la Notaria Mayor de Castilla, por juro de heredad ${ }^{199}$ a Juan.

De su vida politica cabe resaltar que durante la guerra civil castellana apoyó la candidatura de Juana la Beltraneja, frente a Isabel la Católica, siguiendo a sus parientes los Pacheco, pero a mediados de 1476 aban-

19. Fernandez Bethencourt, F., Historia Genealógica y Heráldica de la Monarquia Española. Casa Real y Grandes de España. Madrid 1877-1920, vol. Il, pág. 156.

192 O'Callaghan, J., "Don Pedro Girón...", pág. 387.

${ }_{193}$ Breve del Papa Pio II, dado en Roma, el 16 de abril de 1459. Uhagón, F., Ob. cit, pág. 77. No obstante, Alonso Téllez habia sido legitimado ya en 1456 por una bula de Calixto III, dada en Roma el 22 de abril de 1456. UHAGÓN, F., Ob. cit., pág. 55. Por otra parte, Enrique iV legitimó también a don Juan Téllez por su cédula dada en Segovia, el 30 de julio de 1459. UHAGON. F., Ob. cit, pág. 57.

194 Otorgó su testamento el 28 de abril de 1466 en Villarrubia. A.H.N. Osuna, leg. 2, n." 10. Pub. por Uhagon. F.. Ob. cit., apéndice $n .{ }^{\circ} \mid X$. pág. 91. También le dejaba el cargo de Camarero Mayor de la Cámara de los Paños.

195 Aguado Gonzallez, J., Ob. cit., pág. 275.

196 Ibidem, pág. 275.

19: Si bien accedió al maestrazgo en 1466 a la muerte de su padre, la aprobación de Enrique IV no se obtuvo hasta 1468 , año de la reconciliación del Marqués de Villena con el rey. A.H.N. 1468, octubre, 3. Segovia. Ordenes Militares. Calatrava. Documentos Reales. n." 249, cit. por Solano, E., Ob. cit., pág. 106.

98 A.H.N. Osuna., legajo 3, n. 2 bis (a-b), cit. por Aguado GonzÁlez, J., Ob. cit, pág. 991.

199 El monarca le concedió el oficio con 12.000 maravedies de quitación, el 20 de septiembre de 1469. A.H.N. Osuna, leg. 105, n. 11, cit. por Aguado GonzAlez, J., Ob. cit., pág. 991. Tambièn tenemos noticia de la concesión de este cargo en A.G.S. Q. de C. legajo 14 fol. Juan Téllez Girón, y en la R.A.H. Salázar, M-104, fol. 59 a 60 v, aunque la cédula del rey dada en Segovia por la que hace merced del oficio a Juan Téllez es del 20 de octubre de ese mismo año. 
donó esta causa ${ }^{200}$. El Condestable Pedro Fernández de Velasco actuó como mediador para lograr su reconciliación con los monarcas ${ }^{201}$, quienes le restituyeron sus bienes y oficios, entre ellos la Notaria ${ }^{202}$. Desde ese momento permaneció como fiel servidor de los Reyes Católicos ${ }^{203}$, y colaboró activamente en las campañas militares que condujeron a la conquista de Granada ${ }^{204}$.

\section{LOS NOTARIOS MAYORES DE ANDALUCIA}

La Notaria Mayor de Andalucia estuvo vinculada durante la mayor parte del siglo xv al linaje de los Ribera, familia que tenía dicho cargo desde que Juan I se lo concediese por juro de heredad a Per Afán de Ribera en 1386 por sus servicios a la Corona, oficio que le confirmaría Enrique lll el 16 de enero de $1394^{205}$.

Como fiel servidor del rey, Per Afán mantuvo la autoridad monárquica en los diversos altercados politicos que hubo en el transcurso de estos años en Sevilla, por lo que en 1396 Enrique III, durante su estancia en la mencionada ciudad para pacificarla, recompensó la lealtad de Per Afán con su promoción a Adelantado Mayor de la Frontera o de Andalucia ${ }^{206}$. En los primeros años del siglo xv destacó en algunas de las campañas contra los granadinos, muriendo en una de ellas su primogénito. Al alcanzar Juan II la mayoría de edad en 1419, fue uno de los nobles que formó parte del Consejo Real, y en 1420 parece ser que siguió la parcialidad de Enrique, uno de los infantes de Aragón ${ }^{20}$.

Durante este tiempo Per Afán fue acumulando un rico patrimonio gracias a su colaboración con la Corona y a unos fructuosos enlaces matrimoniales. La muerte de su primogénito Rodrigo López de Ribera, y la vocación eclesiástica de su segundo hijo, Payo Mariño, obligaron al Ade-

200 Aguado González, J., Ob. cit., págs. 276-283

201 Suárez Fernandez, L., Nobleza y Monarquia, pág. 201.

202 R.A.H. Salazar. M-104, fols. $60 \mathrm{v}$ a $61 \mathrm{v}$. Confirmación de los Reyes Católicos del oficio de Notario Mayor de Castilla. Valladolid 1476, sin más data. En la misma colección D-14, fol 269. Cédula de los Reyes Católicos por la que le conceden el título de Camarero mayor de la Cámara de los Paños, 1476, sin lugar y sin más data.

${ }^{203}$ De él dice SuARez Fernandez. L., que fue uno de los brillantes caballeros de la corte de Isabel, en Los Reyes Católicos. Fundamentos de la Monarquia. Madrid 1989, pág. 99.

${ }^{2} 14$ Para más datos sobre este personaje véase la ya varias veces citada tesis de AGUADO GonzÁlez, J., Ob. cit., pág. 284, 342 y suc.

"20.5 Archivo Ducal de Medinaceli (en adelante A.D.M.). Alcalá, leg. 42, n."67, cit. por LADero Quesada, M. A., en “De Per Atán a Catalina de Ribera. Siglo u medio en la historia de un linaje sevillano (1371-1514)». En la España Medieval 4, 1984, pảg. 449, nota 9.

206 Ladero Quesada, M. A., “De Per Afán a Catalina...», pág. 450.

2u Pérez de Guzman, F., Crónica de Juan II, pág. 379. 
lantado a nombrar heredero a Diego Gómez de Ribera, habido en su segunda esposa Aldonza de Ayala ${ }^{208}$.

Según se ha dicho la trayectoria vital de Per Afán de Ribera se inscribe, en conjunto, "dentro de la nobleza de servicio que durante el reinado de Enrique 111 consigue promoverse a los puestos de máxima responsabilidad" ${ }^{209}$. Murió aproximadamente en 1423, siendo enterrado en la Iglesia del Monasterio de Santa Maria de Las Cuevas ${ }^{210}$.

Le sucedió, como ya hemos dicho, Diego Gómez de Ribera, a quien en 1411 Juan Il habia hecho merced del oficio de Notario Mayor de Andalucía, previa renuncia de su padre ${ }^{211}$. Siguiendo la orientación politica paterna apoyó al infante Enrique en 1420 y 1421 , pero tras el fallecimiento de su progenitor, abandonó ese partido, y se puso al servicio del rey Juan II, a quien acompañó en su hueste contra Aragón en 1429 y en el cerco de Alburquerque en $1430^{212}$.

Diego Gómez destacó especialmente en la guerra contra Granada. Como frontero en el obispado de Jaén obtuvo una importante victoria en Colomera, y notables también fueron sus hechos de armas en apoyo de la causa de Yusuf Ibn al-Mawl. De sus entradas en el reino granadino cabe destacar las tomas de Turón, Ardales, Iznajar, Torre de Rute y de la Villa de Castellar ${ }^{213}$.

Su casamiento con Beatriz Potocarrero, hermana de Pedro Portocarrero, señor de Moguer, le aportó una sustanciosa dote -ocho mil doblas-, y unas excelentes relaciones políticas con el Condestable don Álvaro de Luna, con los Bocanegra, con los Méndez Portocarrero, y después con Juan Pacheco, Marqués de Villena ${ }^{214}$. El matrimonio realizó diversas compras con las que acrecentararon considerablemente su patrimonio ${ }^{215}$. Sin embargo, en 1434 se produjo en circustancias trágicas la muerte de

200 Sobre este particular véase LAdero QueSADA, M. A., "De Per Afán a Catalina...", pág. 452, asi como sobre el mayorazgo, bienes, testamento, herederos, etc.. págs. 453-456.

209 Sánchez Saus, R. Caballería y linaje en la Sevilla medieval. Estudio genealógico y social. Cádiz 1989, pág. 379.

${ }^{10}$ Ortiz de Zuñiga, Anales Eclesiásticos y Seculares de la Muy Noble y Muy Leal Ciudad de Sevilla. Sevilla 1893, t. II, pág. 128.

21 A.D.M. Alcalá, legajo 42, n. ${ }^{\circ} 68.1411$, octubre, 13. 1411, noviembre, 4. Per Afán cede dicho cargo a favor de su hijo Diego, cit. por LADERo QueSADA, M. A., en "De Per Afán...", pág. 452, nota 23.

21\% Pérez de Guzman, F., Crónica de Juan II, pág. 477.

213 Sanchez Saus, R., Ob. cit., pág. 380.

214 Ladero Quesada, M. A..: «De Per Afán...», pág. 464.

2: Todos los cambios operados en el patrimonio, adquisiciones, compras y demás, los detalla exhaustivamente LADERO QUESADA, M. A., en su articulo tantas veces citado "De Per...", págs. 464-465. 
Diego en Alora, durante el transcurso de una campaña contra el reino Granadino ${ }^{216}$.

Cuando murió Diego Gómez de Ribera, su sucesor, Per Afán, contaba tan sólo catorce años de edad, por lo que su madre Beatriz Portocarrero tuvo que hacerse cargo temporalmente de la familia. Gracias a sus excelentes relaciones con don Álvaro de Luna, fruto de cierto parentesco, y a la muerte de su marido mientras servia a la Corona, Beatriz consiguió la protección del monarca ${ }^{217}$, quien le mostró su favor permitiéndole mantenter los cargos de Adelantado y Notario, mientras Per Afán fue menor de edad, así como poder seguir cobrando las quitaciones y derechos que tenia Diego Gómez.

Per Afán estuvo siempre al servicio de Juan II y de don Álvaro de Luna, por lo que colaboró con ellos contra los infantes de Aragón. Durante 1441 mantuvo una actividad politica intensa apoyando al monarca, que le recompensó en noviembre de ese mismo año con la concesión de la villa de Alcalá de los Gazules, con su término, tierra y jurisdicción ${ }^{218}$. Como Adelantado de Andalucia actuó en el reino de Jaén y en Jérez de la Frontera pero se dedicó primordialmente a los asuntos internos del reino castellano $^{219}$, sirviendo con gran lealtad a Juan II. Por ello se ganó el aprecio del rey, sobre el que llegó a ejercer cierta influencia, especialmente tras la ejecución de don Álvaro.

Desde 1443 Per Afán estaba desposado con Maria de Mendoza ${ }^{220}$, con la que no tuvo descendientes varones, solo cinco hijas. En 1447 creó mayorazgo a favor de la primogénita Beatriz ${ }^{221}$. Per Afán moriría en la segunda mitad de 1454 en Valladolid, donde estaba la Corte ${ }^{222}$. Ese mismo año habia renunciado el oficio de Notario Mayor de Andalucia en Pedro

${ }^{216}$ Fue enterrado en La Cartuja de Las Cuevas. Sanchez Saus, R., Ob. cit., pág. 380.

21) SAnchez Saus, R, Ob. cit. pág. 384.

${ }^{218}$ A.D.M. Alcalá, legajo 75, n. ${ }^{\circ} 28$, Carta real de Toro, 25 noviembre de 1442, cit. por Ladero Quesada. M. A., “De Per Atán...”, pág. 467. El señorio le fue confirmado por privilegio rodado en 1457.

219 Fernández Gomez, M., “Aproximación al Adelantamiento de Andalucia en el siglo xv", Archivo Hispalense, n. ${ }^{\circ} 221,1989$, pág. 44.

${ }^{220}$ Según señala SAnchez Saus, Ratael, en Ob. cit., pág. 384, citando a Fernàndez de Bethencourt, Per Atán caso primero con Teresa de Córdoba Arellano, hija del señor de Aguilar, don Pedro Fernández de Córdoba, y de Leonor de Arellano, con la que no tuvo descendencia. Fernández de Bethencourt, F., Ob. cit vol. VI, pág. 72. Por otro lado, Maria de Mendoza era hija de iñigo López de Mendoza, futuro Marqués de Santillana, y de doña Catalina Suárez de Figueroa.

221 Ladero Quesada, M. A., “De Per Afán...”, pág. 468.

${ }^{222}$ Fue enterrado, al igual que su padre, en la cartuja de las Cuevas. Sanchez Saus, R., Ob. cit., pág. 384 . 
Lasso de la Vega, hijo de su suegro Iiñigo López de Mendoza, I Marqués de Santillana ${ }^{223}$, aunque no sabemos cuáles fueron los motivos ni las condiciones para efectuar esta renuncia ${ }^{224}$.

De la actividad política de Pedro Lasso destaca la colaboración con su padre en diversas campañas contra los granadinos, por lo que estuvo presente en la conquista de Huelma y en la batalla de la Higueruela ${ }^{225}$. Respecto al oficio de Notario, apenas lo disfrutó pues falleció en $1455^{226}$ en Toledo. Le sucedió en el cargo de Notario Mayor de Andalucia su hermano Î̃̃igo López de Mendoza, el 17 de enero de $1455^{227}$. İñigo también habia estado en las campañas contra Granada junto a su padre y Pedro Lasso ${ }^{228}$. En 1449 el Marqués de Santillana le habia hecho mayorazgo con la villa de Tendilla, de la que Enrique IV le haria conde hacia 1468, como recompensa quizá por sus fieles servicios durante algunas de las revueltas nobiliarias que sacudieron su reinado ${ }^{229}$, ínigo falleció el 17 de febrero de 1479 en Guadalajara ${ }^{230}$, aunque no sabemos con precisión hasta cuando tuvo la notaria.

Según consta por la documentación, el siguiente Notario Mayor de Andalucia fue Pedro Enriquez, hijo del Almirante Fadrique Enriquez. Pedro casó en 1460 con Beatriz de Fibera, matrimonio que había concertado en enero de 1457 Maria de Mendoza, madre de ésta última y viuda de Per Afán de Ribera, con el apoyo de su progenitor, íñigo López de Mendoza ${ }^{231}$. En virtud de los capitulos matrimoniales, Pedro aportaria a dicho enlace el señorio de Tarifa, que su padre se había comprometido a dejarle en herencia ${ }^{232}$, Beatriz su mayorazgo y el oficio de Adelantado Mayor de Andalucia. Al parecer Per Afán de Ribera habia solicitado al rey en una claúsula de su testamento que el Adelantamiento fuese otorgado

23 Su madre era Catalina Suárez de Figueroa. Pedro Lasso casó con Juana Carrillo, hija del caballero Juan Carrillo de Toledo, señor de Mondéjar. Recibió por su matrimonio la villa de Valfermoso. Layna Serrano, F., Ob. cit., págs. 33-34.

${ }_{224}$ A.G.S. Q. de C., legajo 1, fol. 203, cit. por Gomez Izoulerdo, A., Ob. cit., pág. 78.

mb Layna Serrano, F., Ob. cit, pág. 34 435

${ }^{226}$ Según declaran unos testigos a los contadores del rey. A.G.S. Q. de C., legajo 3, fol

22 A.G.S. Q de C., legajo 3, fols. 434-436. El rey le hace merced del oficio de Notario Mayor de Andalucia "...segund e por la manera que la tenía de mi Pedro Lasso vuestro hermano, que es finado...".

${ }^{228}$ Para más datos sobre la biografía de este personaje puede consultarse la obra citada de Layna Serrano, F., Ob. cit., págs. 24 y siguientes.

${ }^{229}$ Ibidem, págs. 26 y 27

230 Ibidem, pág. 28.

${ }^{31}$ R.A.H. Salazar, M-50, fols. 63-75, Guadalajara, 31 de enero de 1457, cit. por LADERO Quesada, M.A., “De Per Afán...”, pàg. 470

232 Ibidem, págs. 470-471. 
al futuro marido de su hija primogénita Beatriz, ya que no tenia descendencia masculina ${ }^{233}$. Enrique IV acatando la voluntad de su vasallo y siguiendo el consejo del marqués de Santillana, reconoció en 1459 a Maria de Mendoza, mujer del difunto Per Afán e hija del Marqués, como administradora del Adelantamiento y de los oficios anejos hasta que su hija contrajese matrimonio ${ }^{234}$. Por tanto, al casarse Beatriz de Ribera en 1460 con Pedro Enriquez, él como marido debia recibir el cargo de Adelantado, aunque no fue nombrado para dicho oficio hasta enero de $1465^{235}$. De este año es curiosamente la primera mención de Pedro Enriquez como Notario Mayor de Andalucia, por lo que puede pensarse que Per Afán hubiese renunciado la Notaría en su cuñado Pedro Lasso, con la condición de que se traspasase dicho oficio al futuro marido de su hija como habia establecido con el Adelantamiento, pero no hay noticias seguras ${ }^{236}$, porque nada se dice al respecto en los capitulos matrimoniales.

Beatriz de Ribera falleció en 1469. De su matrimonio con Pedro Enríquez habian nacido dos hijos, Francisco Enriquez de Ribera, y María de Ribera ${ }^{237}$ Tras dejar la tutela de sus hijos a su suegra e instalar su residencia en Palenzuela, Pedro, al parecer por presiones paternas, decidió contraer matrimonio con la hermana de su difunta esposa, Catalina de Ribera. Su suegra, María de Mendoza se opuso al enlace, pero él ganó dispensa pontificia en diciembre de 1474 e inmediatamente se celebró el matrimonio ${ }^{238}$, del que nacerian otros dos hijos, Fadrique y Fernando.

Entre 1471 y 1476 , Pedro Enríquez mantuvo una actividad politica muy intensa en Sevilla apoyando al Duque de Medinasidonia, ya que los Reyes Católicos la habian apartado de la guerra con Portugal para encargarle de la pacificación de la turbulenta región andaluza ${ }^{239}$. Colaboró también este personaje en la guerra de Granada, especialmente en la conquista

233 Tesiamento dado en Valladolid, 2 de julio de 1454. A.D.M. Alcalá 5-17, cit. por FERNÁNDEZ GOMEZ, M., "Aproximación al Adelantamiento...", pág. 44.

${ }^{234}$ 1459, abril, 2. Olmedo. A.D.M. Alcalá, 42-52, cit. FERnÁndez Gómez, M., “Aproximación al Adelantamiento...", pág. 44.

${ }^{235}$ Nombramiento dado en $\mathrm{O} /$ medo, el 8 de enero de 1465 . Todavia en 1464 el rey confirmaba en el uso del cargo a Maria de Mendoza. A.D.M. legajo 42, núms. 52 a 54, cit. por Ladero Quesada, M. A., "De Per Afán...", pág. 472.

${ }^{236}$ En una noticia existente en la R.A.H. Salázar, M-43, fols 182-184v, aparece Pedro Enriquez como Adelantado Mayor y Notario Mayor de Andalucia en 1465.

${ }^{233}$ Sánchez Saus, R., Ob. cit., pàg. 374.

${ }^{238}$ La dispensa pontificia en R.A.H. Salazar, 9/849, fol. 182. También en A.D.M. Alcalá, legajo 10, fol. 17, cit. por Ladero Quesada, M.A., "De Per Afán...", pág. 474. Sobre los pormenores de este matrimonio véase el relato de PALFNCIA, Alonso de, en Ob. cit., t. $I I$, pág. 26.

${ }^{239}$ González Moreno, J., "Don Fadrique Enriquez de Ribera, I Marqués de Tarifa. Archivo Hispalense, n. ${ }^{\circ} 122,(1963)$, pág. 205. 
de Alhama en 1482 donde participó con sus tres hijos, y en las campañas más importantes organizadas por los Reyes Católicos, como las de Lora, Málaga y Almeria en 1487 y $1489{ }^{240}$, y la de Granada en 1492. Este mismo año tras un duro invierno de guerra enfermó. Sus dolencias se fueron agravando hasta que fallecio el 8 de febrero de $1492^{241}$.

Le sucedió su primogénito Francisco Enriquez de Ribera en sus principales bienes y en el oficio de Adelantado Mayor de Andalucia, cargo que los monarcas le confirmaron ${ }^{242}$. En lo que a la Notaria se refiere, parece ser que Pedro Enriquez se la dejó a su hijo Fernando Enriquez, pues fue nombrado Notario mayor de Andalucía por los Reyes el 6 de marzo de 1492, en el Real de Santa Fé ${ }^{243}$. Sin embargo, Fernando debió renunciar el oficio en su hermanastro Francisco, que el 6 de noviembre de ese mismo año recibia por merced regia dicho cargo ${ }^{244}$.

La muerte de Francisco Enríquez sin herederos en 1509, supuso que todos los bienes y los oficios, incluida la notaria, pasasen a Fadrique Enriquez de Ribera, quien el 13 de enero de 1514 recibió el titulo de Marqués de Tarifa ${ }^{245}$.

LOS NOTARIOS MAYORES DE GRANADA

Contrariamente a la tendencia seguida por los monarcas anteriores, los Reyes Católicos, cuando crearon la Notaría Mayor de Granada en 1492, no la concedieron a un alto noble, sino que la otorgaron a Fernando Álvarez de Toledo, hombre de confianza de los monarcas, quien en 1498 la renunciaria en su hijo Antonio.

\subsection{La Notaria Mayor de los Privilegios Rodados}

Según Salazar de Mendoza dicha Notaría apareció durante el reinado de Pedro $\mathrm{I}^{246}$. Antes de su creación el mandato para la expedición de los

790 Ibidem, pág. 45 .

241 Ladero Quesada, M. A., “De Per Alán...». pág. 208.

${ }^{242}$ Ibidem, pág. 208.

243 A.G.S., Q. de C., legajo 14, fol. 847, cit. por Solana VILLAMOR, M. C., Ob. cit., pág. 30

${ }^{244}$ A.D.M., legajo 42, n. ${ }^{\circ} 71$, cit. por Ladero Quesada, M. A., “De Per Afán...", pág. 473.

245 A.D.M. Medinaceli, 1-19, cit. por FernAndez Gomez, M., "Aproximación al Adelantamiento...", pág. 51. y Gonzalez Moreno, J., «Don Fadrique...» pág. 217. Este último dice que el nombramiento fue en el mes de noviembre.

246 Salazar de Mendoza, Origen de las dignidades seglares de Castilla y León. Madrid 1794, pág. 112. Véanse sobre este oficio los estudios de Martin Postigo, M. de la S., "Notaria Mayor de los Privilegios y Escribania Mayor de los Privilegios y Confirmaciones en la Cancilleria real castellana», Actas de las Primeras Jornadas de Metodologia Aplicada a las Ciencias Históricas, V. Paleografia y Archivistica. Santiago de Compostela 1975, págs. 241254; Diaz Martin, L. V., Los oficiales de Pedro I de Castilla. Valladolid 1975, págs. $92-93$ y Torres Sanz, D., Ob. cit., pág. 105. 
privilegios rodados provenia del Canciller del Rey, del Notario del Rey o de los notarios de los reinos.

Su función exclusiva era el libramiento de los privilegios rodados especialmente solemnes.

Enrique II en las Cortes de Toro de 1369 fijó los derechos que dicho funcionario debia cobrar: "Otrosi tenemos por bien e mandamos que el nuestro notario de los previllejos rodados que lieve por el marco que ha de aver de los previllejos a çiento e sesenta maravedis" ${ }^{247}$, cantidad ésta idéntica a la percibida por los Notarios mayores de los reinos, tal y como se establece en la misma ordenanza.

Este cargo, al igual que los restantes cargos de la Cancillería que hemos estudiado, no fue desempeñado directamente por sus titulares, sino por medio de lugartenientes.

Durante el reinado de Enrique IV se separó la expedición de los privilegios confirmatorios de la de los de nueva concesión. Para los primeros se creó en la Contaduria de Hacienda una nueva Escribania: la Escribania Mayor de los Privilegios y Confirmaciones ${ }^{248}$.

A diferencia de lo que ocurre con las restantes notarias mayores, a lo largo del siglo xv la Notaria Mayor de los Privilegios no recayó en miembros de la más alta nobleza castellana, sin embargo, no hemos considerado oportuno emitir su estudio dado el relevante papel político de sus titulares.

En el reinado de Juan II, desde 1444, ejercia la Notaria Mayor de los Privilegios Rodados el doctor Fernando Diaz de Toledo, quien además tenia los cargos de relator desde 1419, escribano de cámara desde 1420, oidor de la Audiencia desde 1423, refrendario desde 1435, así como los de secretario y tenedor de los sellos de la Cancilleria de la reina doña Juana ${ }^{249}$. Fernando debió ser uno de los hombres de confianza del rey como lo demuestra la gran acaparación de oficios, su destacada labor como Consejero, y su presencia en diversos acontecimientos politicos importantes acompañando al monarca ${ }^{250}$. En 1455 renunció sus cargos en su hijo Luis Diaz de Toledo para que los ejerciese después de su

24/ Cortes..., t. II, pág. 168, cit. en Pascual Martinez, L., «La Cancilleria de Enrique II de Castilla», pág. 186, y en Martín Postigo, M. de la S., La Cancilleria castellana de los Reyes Católicos, pág. 182.

${ }^{248}$ Martin Postigo, M. de la S., "Notaria Mayor de los Privilegios...», pág. 248 y suc.

249 Véase Gomez Izouierdo, A., Ob. cit., págs. 74-78

${ }^{250}$ Una breve reconstrucción de su actividad politica en lbidem, págs. 75 y 76 
muerte ${ }^{251}$, que al parecer tuvo lugar en 1457, porque este año Enrique IV concedía a Luis los maravedies de su padre ya fallecido ${ }^{252}$. Los Reyes Católicos también le confirmaron las mercedes y oficios paternos ${ }^{253}$.

Luis Diaz renunciaria su cargo de Notario Mayor de los Privilegios Rodados en su posible pariente Fernando Alvárez de Toledo. Este personaje de origen judeo-converso ${ }^{254}$, gracias a la influencia de su padre, que habia sido doncel de Juan II, entró en la Corte, donde comenzó siendo Guarda y contino de Enrique IV, monarca que recompensaria su fidelidad con diversas mercedes y favores. En 1474 obtuvo el cargo de Escribano Mayor de las Rentas de la ciudad de Toledo que habia comprado al Comendador Francisco de León ${ }^{255}$. Desde comienzos del reinado de los Reyes Católicos inició una intensa carrera cortesana colmada de oficios, pues estos monarcas le concedieron en 1475 la Escribanía Mayor de los Privilegios y Confirmaciones ${ }^{256}$ y el cargo de Tesorero en $1476{ }^{257}$. También parece ser que fue Contador ${ }^{258}$, secretario ${ }^{259}$, y Consejero real ${ }^{260}$, además de ejercer el oficio de Concertador y Confirmador de los Privilegios en nombre del protonotario apostólico don Esteban de la Hoz que se habia marchado a la Corte Vaticana ${ }^{261}$.

${ }^{251}$ A.G.S. Q. de C., legajo 3, fol. 48. Según dice el documento Juan II le había concedido facultad para renunciar en su hijo los oficios de Notario mayor de los Privilegios Rodados, oidor, refrendario, relator, secretario y del Consejo, por lo que solicita a Enrique IV la confirmación, en Segovia, 4 de marzo de 1455. Luis Diaz cobraba 18.000 maravedies de quitación por Notario mayor de los Privilegios hacia 1454 , según consta en A.G.S. Q. de C., legajo 4 , fol. 57 , quizá en virtud de la primera renuncia de su padre.

252 A.G.S. Q. de C., legajo 3, fol. 52, cit. por Gomez IZoulerdo, A., Ob. cit., pág. 75.

253 A.G.S. R.G.S. 1475, abril, 2. Valladolid, fol. 384. Se le confirman los oficios de Oidor, refrendario, relator, secretario y notario. publ. por MARtin POSTIGo, $M$ de la $S$., Ob. cit., págs. 299-303

254 Sobre este particular véase Rábade Obrado, M. P., Los judeoconversos en la corte y en la época de los Reyes Católicos. Madrid 1990. Universidad Complutense, págs. 509-515.

zss Véase R.A.H. Salazar, C-7, fol. 193 y ss; y A.G.S., Patronato Real, legajo 49, fol. 101. cit. por Rabade ObRado, M. P., Ob. cit., pág. 545.

${ }^{256}$ Medina del Campo, 16 de marzo de 1475. A.G.S. Q. de C., legajo 14, fol. 422. y ss, cit. por Rábade Obrado, M. P., Ob. cit., pág. 749.

zst El 8 de junio de 1476. A.G.S. M. y P., leg. 93, fol. 71. Rábade Obrado, M. P., Ob. cit., pág. 749

258 Ibidem, pág. 749.

:9ulgar, Fernando del, Ob. cit., pág. 168 y R.A.H. Salazar, C-7, fol. 222r, cit. por Rabade Obradó, M. P., Ob. cit., pág. 748.

${ }^{260}$ Véase Rabade Obrado, M. P., Ob. cit., pág. 748.

${ }^{26}$ A.G.S. Consejo Real, legajo 78, n. $^{3}$ y Cámara de Castilla, leg. 1. Este oficio lo ejerció como lugarteniente durante veinte años hasta que muerto el protonotario de la Hoz, sus familiares exigieron que entregase los derechos que como tal habia percibido durante dichos años. Martin Postico, M. de la S., La Cancilleria castellana de los Reyes Católicos, págs. 215-216. 
Importante jalón en su carrera fue su nombramiento en 1488 como Notario Mayor de los Privilegios y Confirmaciones en virtud de la renunciación a la que haciamos antes referencia ${ }^{262}$. Antes de 1491 logró un nuevo oficio, el de Escribano Mayor de la Rentas de las Merindades de Castilla la Vieja, Bureba, Rioja, Aguilar de Campoó, Liébana y Pernia ${ }^{263}$. En 1492 accedió a un cargo recien creado, el de Notario Mayor del Reino de Granada, que le fue concedido en premio a sus servicios ${ }^{264}$. También se tienen noticias de su presencia en la Contaduria Mayor de Cuentas de la Orden de Santiago ${ }^{265}$, de que fue Secretario de la Orden de Alcántara, Escribano Mayor de Rentas de la Merindad de Asturias, y Alcaide de Andarax ${ }^{266}$, así como de que estuvo al frente de la Escribania Mayor del Marquesado de Villena ${ }^{267}$.

Fernando renunció en 1490, la Notaria de los Privilegios y Confirmaciones en Gonzalo de Baeza, Contador del príncipe Juan ${ }^{268}$ y en $1498^{269}$ la del Reino de Granada, en su primogénito Antonio Álvarez de Toledo, quien también tuvo la Escribania mayor de Reantas de la ciudad de Toledo y su Arcedianazgo ${ }^{270}$. Finalmente los Reyes Católicos recompensaron sus muchos servicios con la concesión en 1496 del titulo de Conde de Cedillo para su hijo, aunque con la condición de que no lo usase hasta la muerte de su padre ${ }^{271}$.

A Gonzalo de Baeza le sucedió en el oficio su hijo Juan Rodriguez de Baeza, a quien la reina nombró Notario Mayor de los Privilegios en 1498 para recompensar los servicios de su padre quien le habia suplicado concediese el cargo a su hijo ${ }^{272}$.

26? A.G.S. Q. de C., leg. 14, fol. 422 y ss. La renuncia fue hecha en Sevilla, el 1 de octubre de 1488, y el nombramiento fue dado por los monarcas en Valladolid el 13 de noviembre de 1488. Publ por Martín Postigo, M. de la S., Ob. cit., págs. 304-308.

263 A.G.S. R.G.S. s.d. junio 1491, fol. 24. Real de la Vega de Granada.

${ }^{264}$ Concesión hecha en el Real de Santa Fe, el 30 de enero de 1492, A.G.S. Q. de C., legajo i4, fol. 422 y ss

265 Este cargo, que ejerció al menos desde 1493, to mantuvo durante todo el reinado de los Reyes Católicos. A.G.S. Libros de Cédulas de Cámara, libro 9, fol. 79, n. 590, datada en Mediria del Campo, a 15 de abril de 1504, cit. por Rábade Obradó, M. P., Ob. cit., pág. 750.

266 Rabade Obrado, M. P., Ob. cit, pág. 750. Este oficio lo tuvo hasta 1498.

267 Ibidem, pág. 751.

${ }_{268}$ A.G.S. Q. de C., leg. 28. Córdoba, 15 de octubre de 1490, cit. por Rábade Obrado, M. P., Ob. cit., pág. 752 .

269 A.G.S. R.G.S. 15 de marzo de 1498, fol. 57, Alcalá de Henares. A.G.S. Q. de C., leg. 7, fols. 836-837.

170 A.G.S. R.G.S. 15 de marzo de 1498 , fol. 56 . Alcalá de Henares, cit. por Rabade Obrado, M. P., Ob. cit., pág. 752 .

271 Rabade Obrado, M. P., Ob. cit., pág. 746

22 A.G.S. Q. de C., legajo 28, fol. Juan Rodriguez. Cédula del 15 de octubre de 1498, cit. por Solana Villamor, M. C., Ob. cit., pág. 80. 


\section{Otros oficiales}

Junto a cancilleres y notarios mayores otros muchos oficiales intervenian en el funcionamiento de la Cancilleria real castellana -escribanos, selladores, registradores-, entre los que no encontramos a miembros de los grupos privilegiados.

A pesar de no figurar entre la alta nobleza castellana, dada su proximidad al monarca, los "escribanos" ocuparon una posición privilegiada e influyente dentro de la corte. Muchos autores han afirmado que fueron los escribanos los que llevaron el verdadero peso de la Cancilleria, en lugar de los notarios, que estuvieron más ocupados en otros asuntos ajenos por completo a dicho organismo. Sin embargo, está demostrado que, aunque los Notarios no ejercieran directamente los cargos, solian poner en su lugar a otras personas debidamente cualificadas para que los desempeñaran.

Los escribanos de la Cancilleria, en dependencia directa de los notarios mayores, tuvieron unas funciones genuinamente burocráticas: redacción de privilegios y cartas, sello, registro, vista, etc ${ }^{273}$.

Durante la Baja Edad Media se produjo un desarrollo extraordinario de este oficio ya que se multiplicaron considerablemente las Escribanias para hacer frente a la complejidad cada vez mayor de la Administración Central castellana: Escribanias de la Cancilleria, Escribanias de Cámara, Escribania de la Poridad, Escribanias judiciales, Escribanias del Consejo, Escribanias fiscales...

Los «registradores" fueron los escribanos encargados de registrar todo documento expedido por la Cancillería real bajo la dirección superior de los Notarios. Las Partidas dicen "que son puestos para escrivir cartas en libros que han nombres registros" y que lo debían hacer "sin poner nin quitar nada» ${ }^{274}$.

Desde el reinado de Enrique II, sin embargo, este panorama se alteró profundamente constituyéndose un registro autónomo desgajado de las notarias mayores, aunque ubicado en la Cancilleria. Según el Ordenamiento de las Cortes de Toro de 1371 sabemos que al frente de dicho registro habia un registrador que tenia a sus órdenes a una serie de registradores menores. Este registro plenamente individualizado es el que

Tia Vease Torres SAnz, D., Ob. cit., pág. 109-110.

${ }^{274}$ Partidas, III, 19, 8, cit. en SAnChez Belda, L., "La Cancilleria castellana durante el reinado de Sancho IV...", pág. 188 
encontramos durante el siglo xv, tal como se desprende de las crónicas y los Ordenamientos de Cortes del periodo ${ }^{275}$.

Por último, los «selladores» fueron los escribanos encargados de la tenencia y uso material de los sellos reales, bajo la supervisión de cancilleres y notarios y en intima conexión con los registradores. Recibieron en ocasiones el nombre de "tenedores de los sellos". Unos se ocupaban del sello mayor, otros del sello de la poridad y otros del sello del Consejo.

\section{CONCLUSIONES}

La alta nobleza castellana consolidó a lo largo del siglo xv las bases de su predominio social y de su poder económico, al tiempo que ejerció una gran capacidad de participación politica, a pesar del fortalecimiento de la autoridad regia. Dicha intervención en el poder politico se manifestó no sólo al frente de sus estados señoriales o en el gobierno de las principales ciudades castellanas, sino también en el desempeño de los altos cargos de la Casa y Corte, con caracter honorífico.

En la Cancilleria real castellana del siglo xv la presencia de la alta nobleza fue muy importante. Los principales cargos se concentraron en manos de altos nobles durante la mayor parte del siglo, hasta el punto de que se puede hablar de la patrimonialización de los oficios en manos de determinados linajes que los transmiten incluso en sus testamentos. Es el caso, por ejemplo, de la vinculación del oficio de Canciller Mayor del Sello Mayor a uno de los linajes castellanos más poderosos del momento como fue el de los Manrique, condes de Castañeda. Lo mismo sucedió en el caso de las Notarias mayores de los reinos que también estuvieron vinculadas durante la mayor parte del siglo a miembros de determinadas familias, pasando el cargo de padres a hijos durante generaciones. Asi vemos a los Manrique vinculados a la Notaria mayor de León, a los Silva a la de Toledo, a los Ribera a la de Andalucia o a los Téllez Girón a la de Castilla. No ocurrió lo mismo con la Notaria Mayor de los Privilegios Rodados que estuvo durante la mayor parte del siglo en manos de personajes de extracción social inferior, como por ejemplo Fernando Diaz de Toledo y su hijo Luis, pertenecientes al grupo de los letrados. Sin embargo, el cargo cancilleresco que más nos llama la atención por la distinta procedencia social de los personajes que lo detentaron a lo largo de los tres reinados estudiados, es el de Canciller Mayor de la

\footnotetext{
${ }^{2 / b}$ Véase Torres Sanz, D., Ob. cit., pág. 119.
} 
Poridad. La mayoria de estos cancilleres fueron miembros de la alta nobleza castellana: Sancho de Rojas, Diego Gómez de Sandoval, Juan de Luna, Pedro González de Mendoza, Hurtado de Mendoza, etc. Pero, concretamente, durante el reinado de Enrique IV se observó una tendencia por parte del monarca a depositar el cargo en individuos de una extracción social inferior, como fue el caso de Martín Fernández de Vilches o de Miguel Lucas de Iranzo, como consecuencia quizás de la desconfianza puesta por el rey en los nobles. Así vemos durante su reinado hacer carrerá, en éste y en otros ámbitos, junto a los ya citados Martín de Vilches y Miguel Lucas de Iranzo, a personajes tales como Antonio de la Cadena, Andrés de Cabrera o Beltrán de la Cueva.

El desempeño de los altos cargos de la Cancilleria debió ser para la alta nobleza una baza politica importante, además de una considerable fuente de ingresos, pues aunque la mayor parte de los cargos fueron desempeñados por lugartenientes, de su titularidad se deducia el cobro de sustanciosos derechos fijados por arancel. Las motivaciones que impulsaron a la nobleza a mantener la titularidad de los principales oficios de la Cancilleria fueron fundamentalmente el prestigio social dentro de su propio estamento, la rentabilidad económica y la intervención en los asuntos de gobierno que de dichos cargos se derivaba, aunque no fueran desempeñados directamente por ellos. Por citar un ejemplo, en el caso de los Cancilleres mayores, las funciones burocráticas propias del cargo fueron ejercidas de forma efectiva por otros personajes que aparecen en los documentos como "tenedores de los sellos reales" o incluso bajo la denominación de cancilleres. Dichos personajes, nombrados por el rey, sobre los que recayó gran parte del trabajo cancilleresco, pertenecian a grupos sociales más modestos y en muchos casos eran graduados universitarios, pertenecientes al llamado grupo de los letrados, cuyo papel en la Administración fue muy importante, ya que constituyeron un elemento de apoyo para la política de la Corona. Sin embargo, como ha puesto de manifiesto recientemente $M$. A. Ladero, no se debe exagerar tampoco el papel de los letrados en los puestos de la Administración. pues un reciente estudio sobre 1499 cargos de la época de los Reyes Católicos muestra que sólo el 11 por 100 fueron desempeñados por letrados universitarios, aunque el porcentaje aumenta al 59,3 por 100 en cargos judiciales y de práctica legal, y desciende al 5,2 por 100 para cargos militares y gubernativos, mientras que apenas hay letrados en los cargos de la Casa Real ${ }^{276}$.

${ }^{276}$ Ladero Quesada, M. A., Los Reyes Católicos: La Corona y la Unidad de España. Valencia 1989, pág. 122-123. 
La participación de los grandes nobles, en general, en los órganos de gobierno y administración central y, en particular, en la Cancilleria real castellana, debe ser analizada en el plano de la coyuntura politica, pues la situación no fue la misma a lo largo de todo el siglo $\mathrm{xV}$, aunque pueda afirmarse de un modo general que los partidos nobiliarios tuvieron durante la mayor parte de esta centuria suficiente fuerza para impedir el crecimiento de un poder monárquico fuerte, a pesar de que no fueran capaces de crear un proyecto político viable. Esto último se puso de manifiesto en el reinado de Enrique IV, durante la mayor parte del cual el poder se ejerció a través de un Consejo Real dominado por la nobleza.

Sin embargo, como es bien sabido, durante el reinado de los Reyes Católicos la situación cambió considerablemente al producirse el triunfo del poder monárquico. En estos años los reyes trataron de desvincular a la nobleza de algunas de sus intervenciones politicas, pero ésta continuó manteniendo un papel relevante en los cargos de la Casa y Corte, en los oficios militares y en las misiones diplomáticas, fundamentalmente.

Todo ello nos lleva a afirmar que a lo largo de esta centuria la alta nobleza acaparó la titularidad de los altos cargos de la Cancilleria, aunque los oficios fueran desempeñados por miembros de grupos sociales inferiores más capacitados profesionalmente, quienes además gozaron en muchos casos de la confianza del monarca. Por citar algun ejemplo, Alfonso Sánchez de Logroño y Antón Rodríguez de Lillo actuaron como Cancilleres mayores siendo titulares del cargo los condes de Castañeda. En este sentido los datos ofrecidos por la documentación, al contrario de lo que ocurre en el caso de la alta nobleza, son bastante confusos y no permiten la identificación pormenorizada de todas aquellas personas que ejercieron los cargos, por lo que seria necesario un estudio exhaustivo sobre estos personajes que hasta el momento no ha sido abordado.

Por otra parte, el seguimiento de las trayectorias politicas de los distintos personajes permite señalar que, en líneas generales, los monarcas condedian ciertos cargos como premio o recompensa por determinados servicios a la Corona, y que incluso en ocasiones los utilizaron para "comprar" la fidelidad de algunos nobles. Ya en su momento Tomas y Valiente verificó esta tendencia, especialmente en los reinados de Juan II y Enrique IV, porque según afirma el mencionado autor, para estos monarcas los oficios fueron "una de tantas mercedes con que granjearse adictos" ${ }^{277}$.

27 TOMAS Y VALIENTE, F., "Origen bajomedieval de la patrimonialización y enajenación de oficios públicos en Castilla", Actas de / Symposium de Historia de la Administración. Madrid 1970 , págs. $132-133$. 